\title{
Social assistance reform during a period of fiscal stress
}

\section{Stellenbosch Economic Working Papers: 17/10}

KEYWORDS: SOCIAL GRANTS, EFFECTS OF SOCIAL GRANTS, LABOUR MARKET OUTCOMES, ANTI-POVERTY POLICY, SOUTH AFRICA

JEL: H31, H53, I38, J65

SERVAAS VAN DER BERG DEPARTMENT OF ECONOMICS UNIVERSITY OF STELLENBOSCH

PRIVATE BAG X1, 7602

MATIELAND, SOUTH AFRICA

E-MAIL: SVDB@SUN.AC.ZA
KRIGE SIEBRITS DEPARTMENT OF ECONOMICS UNIVERSITY OF STELLENBOSCH PRIVATE BAG X1, 7602 MATIELAND, SOUTH AFRICA E-MAIL: KRIGESIEBRITS@SUN.AC.ZA

\section{UNIVERSITEIT BUREAU FOR ECONOMIC RESEARCH AT THE UNIVERSITY OF STELLENBOSCH 


\title{
Social assistance reform during
}

a period of fiscal stress ${ }^{1}$

\author{
SERVAAS VAN DER BERG AND KRIGE SIEBRITS
}

ABSTRACT

This paper reflects on the current state and likely future of the South African social assistance system, focusing specifically on its fiscal sustainability, its effectiveness as an instrument to combat poverty in a longer-term developmental sense, and its impact on the allocation of resources. Despite showing that the grants system is an effective intervention which markedly reduces poverty and apparently does not have severe undesirable behavioural effects, the paper argues that the scope for strengthening antipoverty policy in South Africa by further expanding the social grants system nonetheless has become very limited. The main policy conclusions of the paper are that sustainable poverty reduction in South Africa requires inclusive job-creating economic growth, and that anti-poverty policy should remain focused on achieving his objective.

Keywords: Social grants, Effects of social grants, Labour market outcomes, Anti-poverty policy, South Africa

JEL codes: H31, H53, I38, J65

\footnotetext{
1 This document was prepared for the Financial and Fiscal Commission (FFC) as one of the technical papers that supported the Commission's recommendations on the division of revenue among the three spheres of government in the 2011/12 financial year. We are grateful to the Commission for funding the research and for permission to make it available in this format.
} 


\title{
Social assistance reform during
}

\author{
a period of fiscal stress
}

INTRODUCTION

Social security systems provide protection against risks of income loss due to contingencies such as old age, unemployment, disability, or injuries sustained at work. The social assistance components of social security systems consist of non-contributory cash or in-kind grants to provide protection to the most needy. During the past two decades, extensive fiscal space and sweeping reforms have enabled South African policymakers to develop an unusually large social grants system by the standards of middle-income countries. ${ }^{2}$ Several factors, however, suggest that South Africa has reached a crossroads in the evolution of the social assistance system: the public finances have deteriorated rapidly and severely as a result of a recession linked to the global economic crisis, large sections of the population have not experienced significant improvements in their standards of living since democratisation, and many South Africans harbour reservations about aspects of the design and impact of the grants. Hence, it is an opportune time to reflect on the current state and likely future of the South African social assistance system.

This paper provides such reflection, focusing specifically on the fiscal sustainability of the grants system, its effectiveness as an instrument to combat poverty in a longer-term developmental sense, and its impact on the allocation of resources. Section 2 outlines the elements, growth and size of the South African social assistance system and comments on its budgetary sustainability. Section 3 explores the effectiveness of the social assistance system as a mechanism for achieving the Government's objective of a developmental approach to poverty alleviation and its efficiency costs in terms of distortions to the allocation of resources. To this end, the section discusses the role of the grants system in the broader context of anti-poverty policy in South Africa and reviews relevant literature on the poverty-mitigating and incentive effects of the grants. Against this background, section 4 discusses the future role of the grants system in South Africa and comments on two sets of possible options for enhancing its effectiveness. These are conditional cash transfer programmes and workfare schemes to expand the access of unemployed members of the labour force to economic opportunities. Section 5 outlines policy implications.

\section{THE SOUTH AFRICAN SOCIAL SECURITY SYSTEM}

\section{$2.1 \quad$ Elements and coverage}

The social insurance component of the South African social security system consists of three contributory funds providing conditional income support or compensation for defined-risk events: the Unemployment Insurance Fund, the Compensation Funds, and

\footnotetext{
2 South Africa had the ninth-highest value in a recent comparison of the ratios of social assistance spending to GDP in 74 developing and transition countries (Weigand and Grosh, 2008: 25-26).
} 
the Road Accident Fund. ${ }^{3}$ In addition, binding industrial-council and other agreements between employers and employees have introduced an element of compulsion into many occupational retirement insurance schemes, thus turning them into quasi-social insurance schemes. ${ }^{4}$ The social assistance system provides means tested income support for members of three vulnerable groups: children, the elderly and the disabled.

The remainder of this section outlines these two components of the South African social security system in more detail..$^{5}$ The discussion revolves around coverage in the three major life stages of individuals and families: childhood, working age, and old age. ${ }^{6}$

\subsubsection{Childhood}

The child support grant, which was introduced in April 1998 to replace the child maintenance grant, currently is the most important form of assistance for children in poor families. These grants are paid to the primary caregivers of children. ${ }^{7}$ Since 1 April 2010, the child support grant amounts to R250 per month, and the number of beneficiaries reached an estimated 9424281 on 28 February 2010 (National Treasury, 2010a: 103, 105). The formula for determining the income threshold for the child support grant is $A=B * 10$, where $A$ is the income threshold and $B$ the monthly value of the grant. Hence, the income threshold now amounts to R2 500 per month for single caregivers and R5 000 per month for married caregivers (R30 000 per annum and R60 000 per annum, respectively).

Care dependency grants are paid to the parents or caregivers of children between the ages of 1 and 18 years who suffer from severe physical and mental disability and are in permanent home care (disabled persons between the ages of 18 and the retirement age receive state disability grants, while those above the retirement age receive old-age pensions). At the end of February 2010 these grants, the value of which increased to R1 080 on 1 April 2010, were paid to an estimated 119307 care-dependent children (National Treasury, 2010a: 103, 105). The means test for care dependency grants is similar to that for child support grants: hence, in April 2010 the income threshold increased to R10 800 per month for single caregivers and R21 600 per month for married caregivers (R129 600 per annum and R259 200 per annum, respectively).

Foster care grants are disbursed to children deemed in need of care by the courts. Such children are placed in the custody of foster parents designated by the courts and

\footnotetext{
3 Social insurance programmes consist of benefits organised by the state and funded by means of specified contributions by employers and employees.

${ }^{4}$ In South Africa, unlike in many other countries, contributions paid by employers and employees are not included in social security taxes, because they do not flow through the coffers of the state. International comparisons of the extent of social security provision based on government spending ratios therefore misrepresent the scope of insurance provision in South Africa.

5 This paper does not discuss the informal insurance component of social security systems (cash or inkind assistance from the extended family and other social networks), which by nature is difficult to influence by means of policy interventions.

6 Two elements are omitted from the discussion: compensation paid to victims of road accidents by the Road Accident Fund, and temporary grant-in-aid relief payments.

${ }^{7}$ Child support grants initially benefitted children under the age of seven years, but the coverage of the programme was expanded gradually and the grant is being rolled out poor children up to the age of 18 over the next three years (National Treasury, 2010a: 104).
} 
supervised by social workers. The aim of the grant is to reimburse foster parents for the cost of caring for children who are not their own; as such, the grant is not means tested and falls away if the child is adopted formally. From 1 April 2010 foster care grants amount to R710 per month and the number of beneficiaries reached an estimated 569215 at the end of February 2010 (National Treasury, 2010a: 103, 105).

\subsubsection{Working age}

The Unemployment Insurance Fund (UIF) provides short-term compensation for qualifying workers. ${ }^{8}$ Employees and employers each contribute 1 percent of the employee's monthly earnings up to a threshold of R12 478 to the UIF, and the proceeds are used to pay benefits to contributors or their dependents in instances of unemployment, illness, death, maternity and adoption of a child. Income replacement rates range from 60 percent for low-income earners to 38 percent for higher-income earners, and benefits are limited to one day for every six completed working days, up to a maximum of 238 days (34 weeks) in a period of four years. On average, the UIF disbursed about R495.8 million per month to 207967 beneficiaries during the first nine months of 2009/10 (National Treasury, 2010a: 107). On 31 March 2009, the Fund's capital and reserves amounted to R34.6 billion, and an actuarial valuation at the time indicated that it would be able to meet its cash-flow requirements over the next ten years for a wide range of possible claims scenarios (National Treasury, 2010a: 107).

The Compensation Funds provide income benefits and medical care to workers injured on the job, funding for the rehabilitation of disabled workers, and survivor benefits to the families of victims of work-related fatalities. The main Compensation Fund is administered by the Department of Labour and covers workers in sectors other than mining and construction, while the Department of Health administers the Mines and Works Compensation Fund, which provides benefits to victims of lung diseases caused by working conditions. Private firms licensed by the Compensation Commissioner administer two other funds: the Rand Mutual Association for workers in the mining industry and the Federated Employers' Mutual Assurance for workers in the building industry. On 31 March 2009, the main Compensation Fund held an accumulated surplus of R6.5 billion and a reserves of R13.9 billion (National Treasury, 2010a: 109).

State disability grants are available to people disabled in circumstances other than road and work-related accidents. The grant is paid to disabled persons between the ages of 18 and the retirement age who do not receive other state grants and who are not cared for in state institutions. Eligibility is determined by strict medical-based criteria: the disability should be permanent and sufficiently severe to prevent the affected person from entering the labour market. Hence, the purpose of the grant is to compensate disabled persons for loss of income. Disability grants have amounted to R1 080 per month since 1 April 2010, and the number of beneficiaries was expected to reach 1310761 by the end of February 2010 (National Treasury, 2010a: 103, 105). The means test formula for the disability grant is $\mathrm{D}=1.3 \mathrm{~A}-0.5 \mathrm{~B}$, where $\mathrm{D}$ is the monthly disability grant, $\mathrm{A}$ the maximum monthly disability grant, and $\mathrm{B}$ the monthly private

\footnotetext{
8 The Unemployment Insurance Act and the Unemployment Insurance Contributions Act do not apply to the following categories of workers: those working fewer than 24 hours per month for an employer, learners, public servants, contracted foreign workers, workers whose earnings consist of commission only, and working earning a monthly old-age social pension.
} 
income of the beneficiary. The threshold monthly private incomes for eligibility are R2 426 for single and R4 852 for married adults (R29 112 per annum and R58 224 per annum, respectively). An additional provision states that grants are not paid to single and married disabled adults whose assets exceed R484 800 or R969 600, respectively.

\subsubsection{Old age}

South Africa has a well-established retirement fund market. The coverage rate for formal-sector employees of about 60 percent is comparatively high by international standards, which indicates the extent to which membership of an occupational fund is accepted as an obligatory condition of employment (National Treasury, 2007a: 5). According to the National Treasury (2007a: 5), South Africa's ratio of pension fund assets to GDP of 63 percent compare favourably with those of countries such as Australia, Chile, Malaysia, Singapore and the United Kingdom.

Coverage rates, however, vary considerably across income categories. Partly because of the favourable tax treatment of retirement saving, most middle- and high-income earners are well covered: almost all formal-sector employees who earn more than R120 000 per annum belong to a pension, provident or retirement fund (National Treasury, 2008b: 100-101). Coverage is much less comprehensive among lower-income earners, however: some 360000 formal employees in the R60 000 to R120 000 income category and fully 2.7 million of those earning less than R60 000 per annum lack retirement coverage. In total, only an estimated 5.9 million of the 8 million formalsector workers (i.e. roughly one-half of the about 12.3 million employed and one-third of the 16.8 million economically active South Africans) have retirement coverage (National Treasury, 2008b: 100). Moreover, early withdrawals and limited access to cost-effective instruments render the income replacement rates for many pension and provident fund members inadequate. Fewer than half of those who reach retirement age with a funded pension receive more than 28 percent of their pre-retirement incomes (National Treasury, 2007a: 5), and the Smith Committee (1995: 18) found that 40 percent of occupational pensions paid had a lower value than the social pension.

Hence, lower-income South Africans (including many formal-sector workers) depend on social pensions in old age. Means-tested pensions are payable to persons of retirement age and older; since 2008, the retirement age for men is being lowered from 65 to 60 years to bring it in line with that of women in 2010. The maximum amount of the grant has been R1 080 per month since 1 April 2010 and an estimated 2534082 individuals received social pensions at the end of February 2010. The means test formula for the social old-age pension is the same as that of the disability grant: $\mathrm{D}=1.3 \mathrm{~A}-0.5 \mathrm{~B}$, where $\mathrm{D}$ is the monthly pension payable, A the maximum monthly pension payable, and $\mathrm{B}$ the monthly private income of the recipient. Single and married elderly persons whose assets exceed R484 800 or R969600, respectively, are not eligible to receive social pensions. At the end of February 2010, some 1248 war veterans received grants subject to the same income and asset thresholds applicable to social pensions. The value of these grants increased to R1 100 per month on 1 April 2010.

\section{$2.2 \quad$ Growth and size}

Government spending on social grants payments increased from R16 027 million (2.3 percent of GDP) in fiscal year 1998 to R71 161 million (3.1 percent of GDP) in fiscal 
year 2009. Data on social security spending indicates that this expansion was part of a longer-term growth trend: outlays on social protection (which include social grants, disbursements by the social security funds and pension payments to former government employees) increased from 6.2 percent of general government spending in fiscal year 1983 to 14.0 percent in fiscal year 2007; that is, from 1.8 percent to 4.5 percent of GDP ( $c f$. Figure 1). ${ }^{9}$ This outcome resulted from various developments that have affected beneficiary numbers and the values of the various grants, including the equalisation of benefits across population and gender groups, adjustments of grant amounts to fully or partially counteract the effects of inflation, the introduction and gradual expansion of the child support grant and increased take-up of disability and foster-care grants.

\section{Figure 1}

\section{General government spending on social protection (1983-2007)}
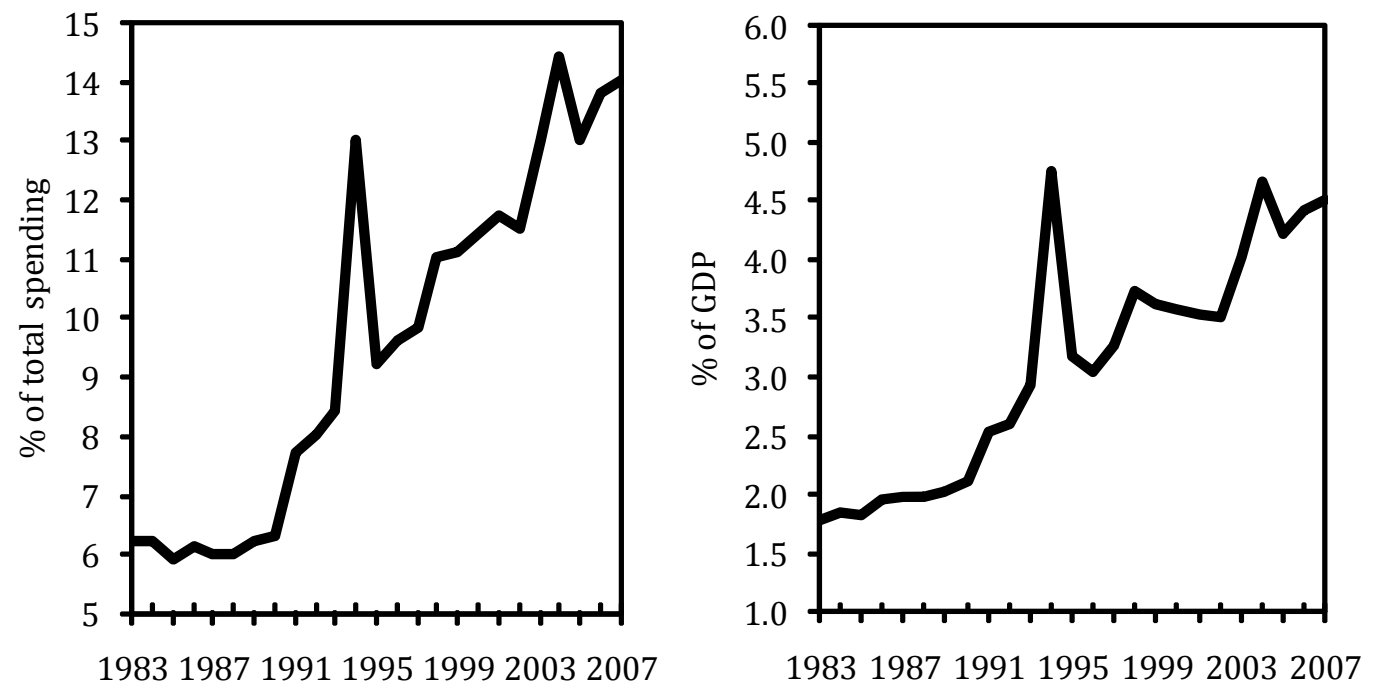

Source: South African Reserve Bank electronic data

The number of beneficiaries of social grants increased from 2889442 in April 1997 to 13114033 in April 2009 (cf. Table 1). More than one quarter of the South African population now receive a state grant - a remarkably high figure for a middle-income country. Although all the grant types except the war veterans' grant experienced significant growth in beneficiary numbers during the past decade, the major driver of such growth in the system as a whole clearly has been the introduction and subsequent expansion of the coverage of the child support grant. Fully 67.3 percent of all grants paid in April 2009 were child support grants; other large categories were old-age pensions (18.4 percent) and disability grants (9.8 percent). Because it is the smallest of the grants in rand terms, however, the child support grant does not dominate social assistance outlays. Thus, the 2010/11 Budget provided for social assistance expenditure of R89 368 million, of which R34 058 million (38.1 percent) was allocated for social pensions, R30 860 million (34.5 percent) for child support grants, R17 379 million

\footnotetext{
${ }^{9}$ The sharp spike in both ratios in 1993/94 resulted from a special transfer amounting to R7 340 million to improve the actuarial position of the Government Employees Pension Fund.
} 
(19.4 percent) for disability grants and R7 071 million (7.9 percent) for other grants (National Treasury, 2010a: 106).

Table 1

Beneficiaries of social assistance grants (1997-2009)

\begin{tabular}{|lrrr|}
\hline Grant & \multicolumn{3}{c|}{ Number of beneficiaries (30 April) ${ }^{1}$} \\
& 1997 & 2003 & 2009 \\
\hline Old age grant & 1737682 & 2022206 & 2414183 \\
War veterans' grant & 12047 & 4594 & 1649 \\
Disability grant & 732322 & 953965 & 1281556 \\
Foster care grant & 41865 & 138763 & 483687 \\
Care dependency grant & 2895 & 58140 & 107134 \\
Child support grant ${ }^{2}$ & 362631 & 2630826 & 8825824 \\
\hline Total & 2889442 & 5808494 & 13114033 \\
\hline
\end{tabular}

Sources: National Treasury (2001; 2007b); South African Social Security Agency (2009)

Notes: 1 The numbers exclude the recipients of grant in aid and social relief of distress.

2 The 1997 number represents parent allowance and child allowance grants.

Figure 2 indicates that the nominal values of all the grants rose markedly between 1994 and 2009. These increases, however, often did not keep pace with inflation, especially during the second half of the 1990s. Accordingly, the purchasing power of the old-age pension, war veterans' pension, disability grant, care dependency grant and foster care grant all increased only modestly between 1994 and 2009. By contrast, the purchasing power of the child support grant has increased markedly in real terms since its introduction in 1998.

\subsection{The budgetary sustainability of the social assistance system}

The rapid growth and size of the South African social grants system have given rise to concern about it longer-term sustainability, within as well as outside of government. In 2004, for example, the National Treasury (2004a: 73) commented as follows on trends in the ratio between social grants expenditure and GDP: "This ratio is high compared to most other developing countries, and also high relative to spending on cash social assistance in some high income countries. Growth of this magnitude relative to GDP raises sustainability questions for the future." In addition, the limited size of South Africa's tax base also has contributed to concern about the sustainability of the social assistance system. In this regard, critics sometimes point to the gap between the numbers of individual taxpayers and beneficiaries of social grants: at the end of February 2009, for example, South Africa had some 2.3 grant recipients for every registered individual taxpayer. ${ }^{10}$

\footnotetext{
10 On 28 February 2009, South Africa had 5540646 registered individual taxpayers and 12972828 grant recipients (National Treasury, 2009b: 6; South African Social Security Agency, 2009: 5).
} 
Figure 2
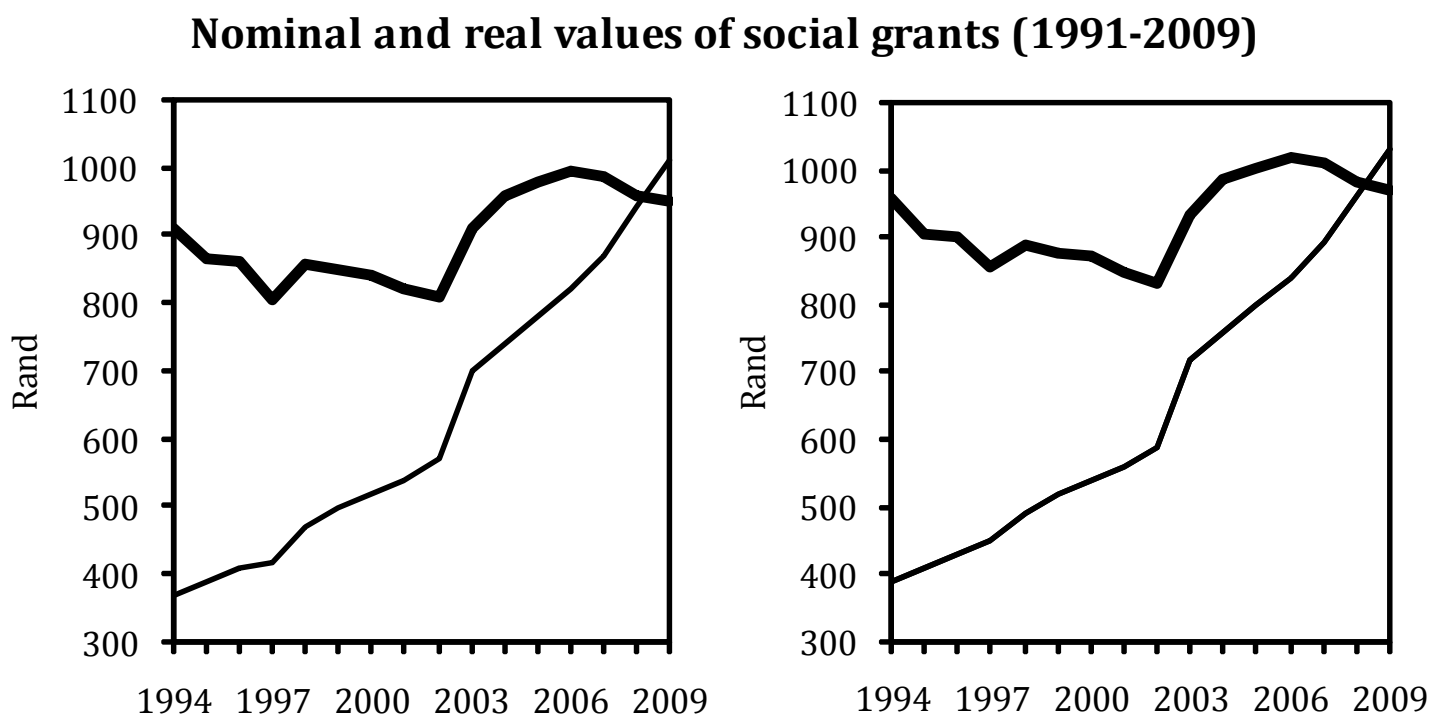

Old-age pension, disability grant, care dependency grant

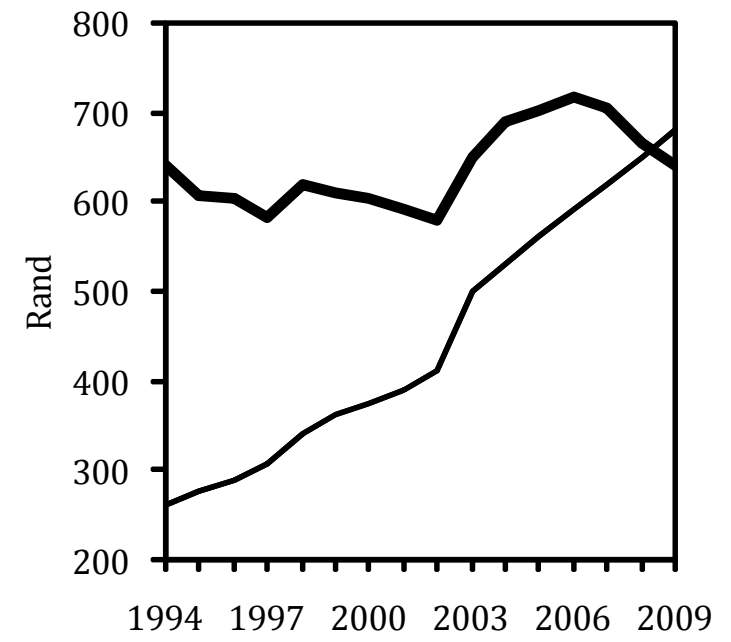

Foster care grant

Current prices

\section{War veterans' pension}

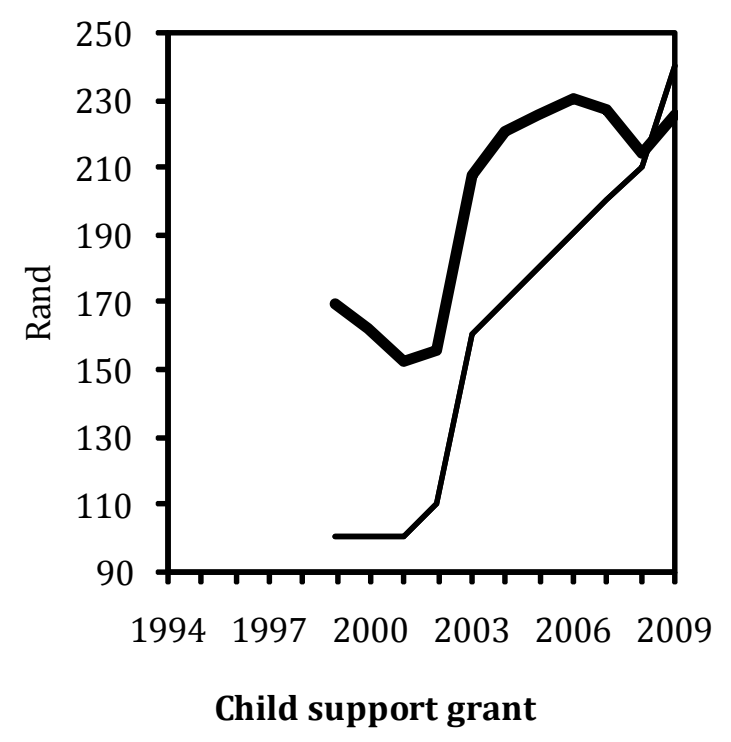

Constant 2008 prices

Sources : National Treasury (various issues); South African Reserve Bank electronic data

Figure 3 shows that the fiscal situation has remained sustainable despite the rapid growth in government spending on grants and other social security programmes from the mid-1980s onwards. ${ }^{11}$

\footnotetext{
${ }^{11} \mathrm{~A}$ fiscal position is sustainable when the public debt burden does not pose the risk of an unmanageable upward deficit-debt spiral leading to debt default, given public spending commitments and tax capacity and compliance. An analysis of fiscal policy in South Africa between 1960 and 2008 by Calitz, Du Plessis and Siebrits (2009) showed that the post-1985 period formed part of a longer-term epoch of fiscal prudence during which South Africa avoided the fiscal policy-rooted macroeconomic crises that plagued many developing countries in Africa and elsewhere during this period.
} 
Figure 3

National government main fiscal aggregates (1985-2009)

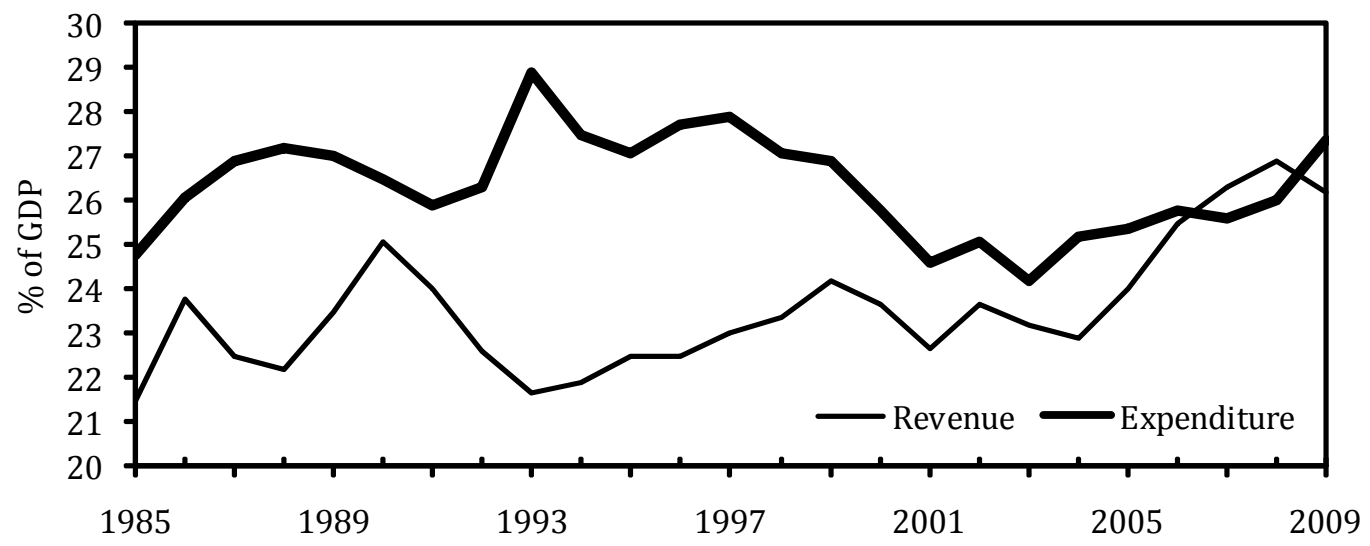

Revenue and expenditure

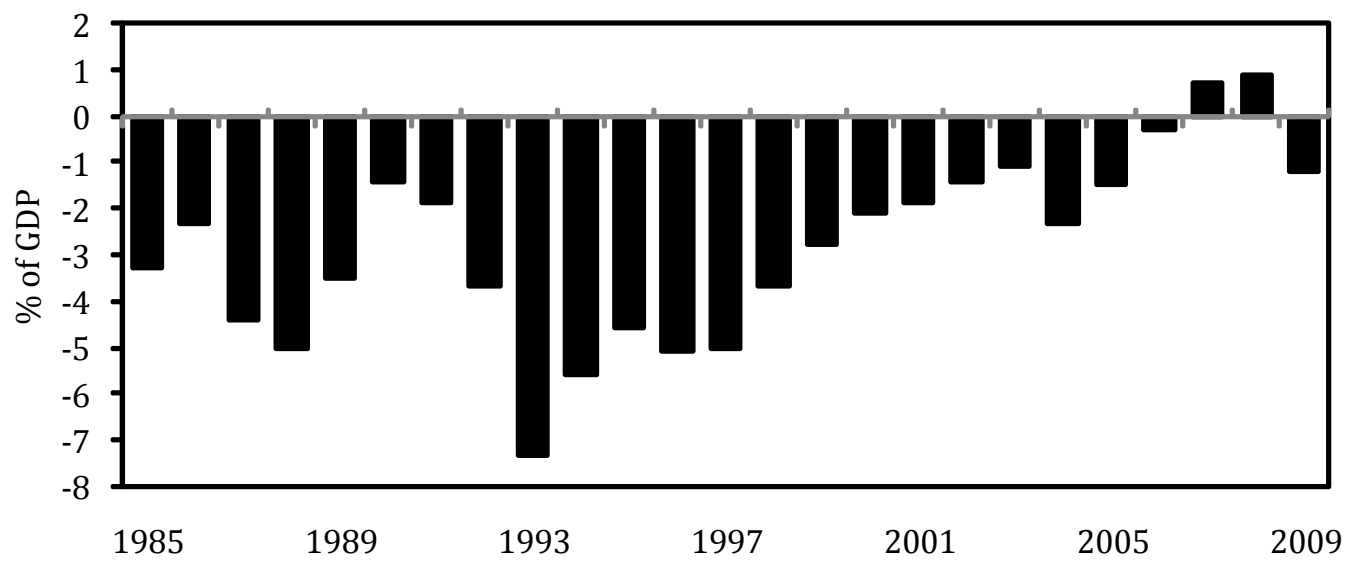

Budget balance (surplus +, deficit -)

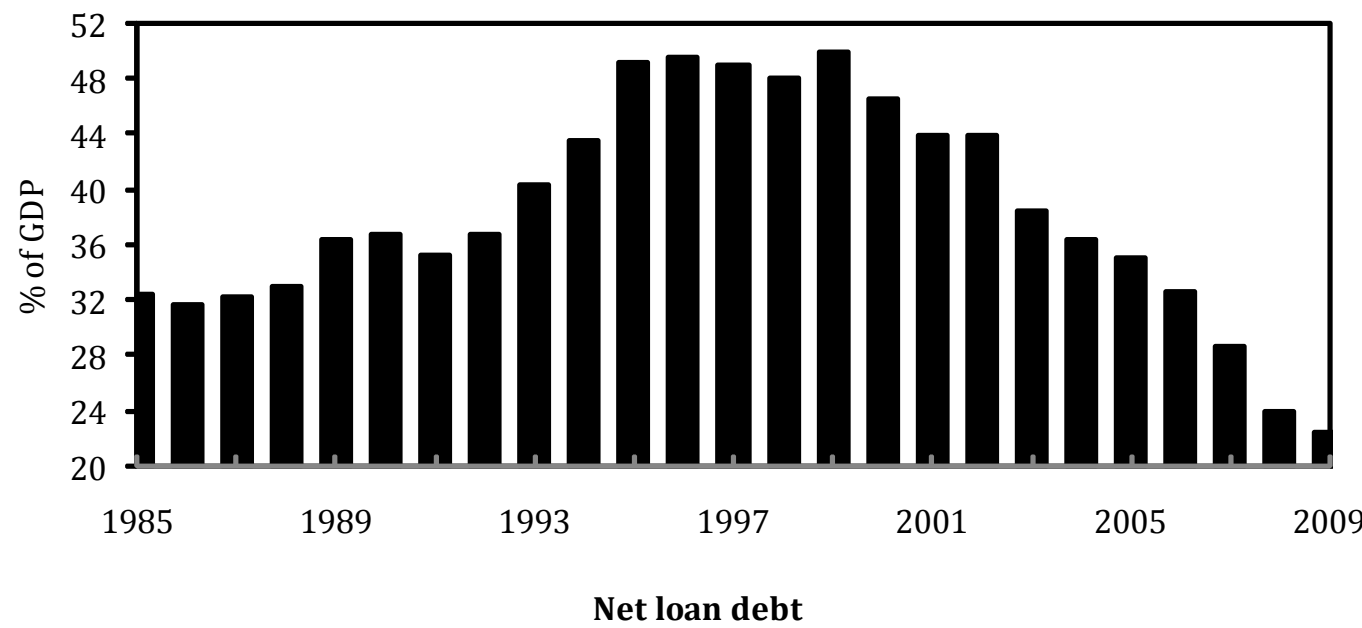

Source: South African Reserve Bank electronic data

The thorough overhaul of tax administration and collection in the second half of the 1990s and sustained positive economic growth from 1994 until 2008 were the main reasons why growing social assistance spending has not caused fiscal problems: the 
consequent rapid growth in tax revenues has enabled the Government to steadily expand social grants spending while reducing budget deficits and the public debt burden during the second half of the 1990s and keeping these aggregates at manageable levels thereafter. ${ }^{12}$ Table 2 highlights how extensive the fiscal space available to the authorities was after the successful conclusion of the fiscal consolidation effort in 2000: from 2001 until 2007, the combination of rapid revenue growth and steady decreases in the interest payments on public debt made it possible to increase the GDP shares of almost all functional spending categories in the context of an expansionary fiscal policy stance which raised general government expenditure from 30.3 percent to 32.1 percent of GDP. Hence, in contrast to the period from 1995 to 2000 (when general government outlays decreased by 4.1 percentage points of GDP), the expansion of social security spending from 2001 until 2007 did not require compensating reductions (as percentages of GDP) in expenditures on other general government functions.

Table 2

Functional classification of general government spending (1995, 2001 and 2007)

\begin{tabular}{|lrrr|}
\hline & \multicolumn{3}{c|}{ Percentages of GDP } \\
\hline General public services & 1995 & 2001 & 2007 \\
Protection services & 4.2 & 3.1 & 5.5 \\
Social services & 5.3 & 4.5 & 4.8 \\
$\quad$ Education & 15.0 & 14.8 & 15.6 \\
$\quad$ Health & 7.0 & 6.2 & 5.8 \\
$\quad 3.1$ & 3.1 & 3.2 \\
Social protection & 3.2 & 3.5 & 4.5 \\
Other social services & 1.7 & 1.9 & 2.2 \\
Economic services & 5.2 & 3.1 & 3.2 \\
Public debt transactions & 4.7 & 4.9 & 2.8 \\
Total & 34.4 & 30.3 & 32.1 \\
\hline
\end{tabular}

Source: South African Reserve Bank electronic data

Table 3 shows that the recent global financial crisis has dramatically changed the fiscal situation in South Africa. The sharp slowdown in economic activity reduced national government tax revenue from 26.9 percent of GDP in fiscal year 2008 to an estimated 23.3 percent in fiscal year 2010; over the same period, expenditures (boosted by countercyclical outlays and the capitalisation of Eskom, inter alia) increased from 26.0 percent of GDP to an estimated 30.6 percent. These developments resulted in a sharp deterioration of the national government's budget balance from a surplus of 0.9 percent of GDP in fiscal year 2008 to a projected deficit of 7.3 percent in fiscal year

\footnotetext{
12 Growing spending on social grants contributed to relatively large budget deficits from 1990 onwards, but was a markedly less important causal factor than several extraordinary expenditures (including drought relief spending and transfer payments to the government pension fund to improve its actuarial position) and the depressing effect on tax revenues of the protracted recession that lasted from 1989 until 1993 (see Calitz et al., 2009: 5-6).
} 
2010. National government gross loan debt is projected to reach 43.1 percent of GDP in fiscal year 2013, up from 27.0 percent in 2009 (National Treasury, 2010a: 61).

Table 3

National government fiscal framework (2008-2013)

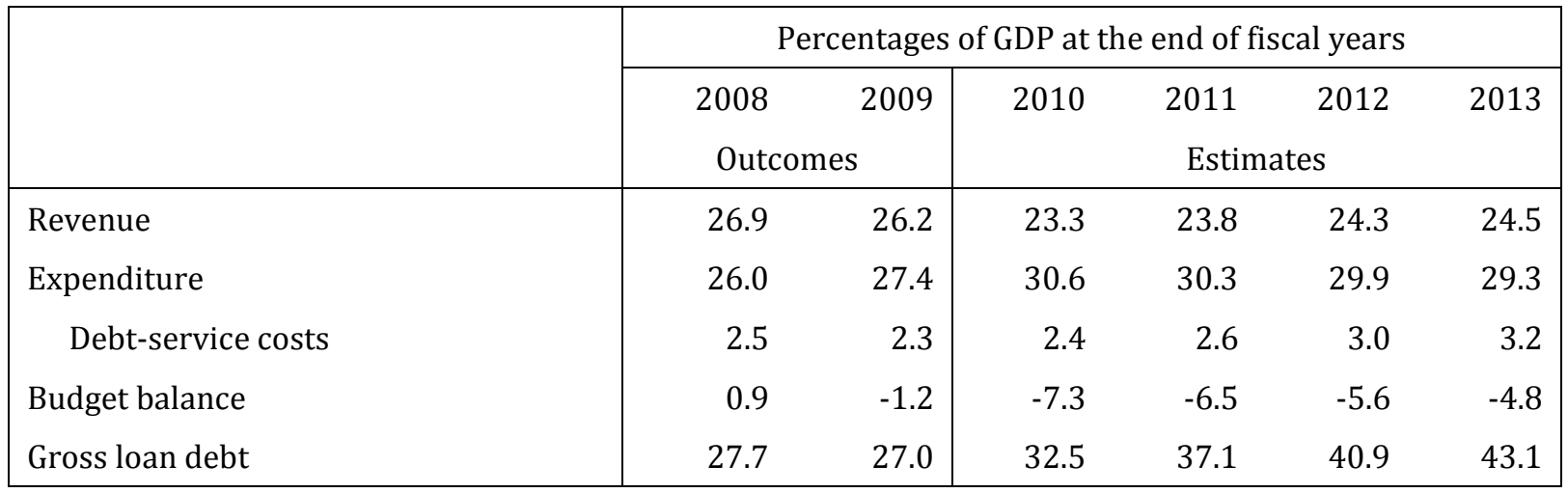

Source: National Treasury (2010a: 61, 93)

Prudent management of the public finances before and during the crisis has left South Africa in a much sounder fiscal position than many other countries, including several member states of the European Union. ${ }^{13}$ Long-term modelling by the National Treasury (2010a: 63) based on an average GDP growth rate of 3.5 percent per annum indicated that the public debt should peak at a modest level of 44 percent of GDP in 2015/16 and decrease thereafter, albeit gradually. Hence, the available information does not suggest that the government spending-to-GDP ratio is likely to increase to such an extent over the next decade that severe cutbacks in social assistance would be required. More generally, revenue growth obviously will be a key factor determining the scope for expanding the social assistance system in the longer run. As was indicated earlier, the rapid growth in expenditure on social grants during the late-1990s and early 2000s was facilitated by exceptionally high rates of growth in tax revenues related to institutional reforms which improved tax administration and collection. Such rates of revenue growth are unlikely to recur once the economy has recovered fully from the effects of the global crisis, and this may well severely constrain future growth in public spending (including outlays on social grants).

In the short to medium term, fiscal consolidation has become unavoidable. Apart from adding large and potentially unsustainable amounts to the public debt, deficits of 7 percent of GDP or more will put upward pressure on interest rates and discourage private investment (especially in the context of the large infrastructure investment programmes to be undertaken by various public corporations in the next few years ${ }^{14}$ ); furthermore, the increases in interest payments resulting from a rapidly growing debt burden could crowd out public spending on priority functions. The 2010/2011 Budget -

\footnotetext{
13 The worst-hit country has been Greece, where the budget deficit has reached 12.7 percent of GDP and the public-debt-to-GDP ratio more than 110 percent (Why Pigs' mess is our concern, 1 March 2010). Ireland, Portugal and Spain have also recorded large fiscal deficits and public debt burdens well in excess of the 60 percent of GDP limit prescribed by the European Union's Stability and Growth Pact.

14 The public sector is expected to spend a total of R846 billion on infrastructure projects during the fiscal years 2011, 2012 and 2013 (National Treasury, 2010a: 66).
} 
which provides for a phased reduction in the budget deficit of the national government to 4.8 percent of GDP in fiscal year 2013 based on a combination of revenue growth and strict expenditure discipline - represents the first step of such a consolidation effort. The Budget provides for a 1 percentage point reduction in the expenditure-to-GDP ratio from fiscal year 2011 to fiscal year 2013 despite an expected increase in the debt costs component of 0.6 percentage points of GDP ( $c f$. Table 3 ). This reduction will be based in part on identified cost savings of R25.6 billion at national-government level and R13.4 billion at the provincial level (National Treasury, 2010a: 117). ${ }^{15}$ The adjustment imperative clearly will leave no room for the introduction of costly new social assistance initiatives between 2011 and 2013, but the Government remains committed to the extension of the child support grant to eligible children up to their $18^{\text {th }}$ birthday during this period.

\section{SOCIAL GRANTS, POVERTY AND DEVELOPMENT IN SOUTH AFRICA}

This section discusses the effectiveness and incentive effects of the South African social assistance system. Section 3.1 outlines the current role of social grants in anti-poverty policy in South Africa. Section 3.2 comments on two aspects of the effectiveness of the social assistance system. First, it shows the extent to which the grants mitigate poverty by augmenting the incomes of poor South Africans. Second, it summarises evidence on the utilisation of social grants by the poor. In this regard, the key issue is whether the grants merely serve as a short-term palliative to poverty or play a developmental role as well (that is, enable poor people to break the cycle of poverty by undertaking incomegenerating activities and accumulating assets). Section 3.3 explores the impact of the grants system on allocative efficiency by identifying its most important incentive effects and empirical evidence on behavioural responses to such incentives.

\subsection{Social grants as a component of anti-poverty policy in South Africa}

The post-apartheid South African Government has consistently stressed the importance of job-creating economic growth as a mechanism for reducing poverty, arguing that growth creates economic opportunities which enable poor households to earn better incomes through jobs or self-employment. ${ }^{16}$ Accordingly, the period since 1994 has seen the genesis of two strategies to accelerate economic growth, namely Growth, Employment and Redistribution (Gear - 1996) and the Accelerated and Shared Growth Initiative South Africa (Asgisa - 2005). Mindful of the high incidence of unemployment and deprivation in South Africa, however, the Government has also used a wide range of interventions to enhance the poverty-mitigating impact of economic growth ( $c f$. Altman and Hemson, 2007: 8; The Presidency, 2008: 13-14):

\footnotetext{
15 The expenditure implications of this deficit-reduction strategy pose particular challenges to the provinces, whose current spending increased rapidly in 2008 and 2009 as a result of employment growth, significant general salary increases and the implementation of occupation-specific salary dispensations (mainly in education and health).

${ }^{16}$ As the National Treasury (2010a: 2, 5) put it: "Our future depends on finding a more inclusive economic trajectory, characterized by more rapid growth in gross domestic product (GDP) and job creation... Increasing employment is the only sustainable solution to reducing poverty and inequality".
} 
- $\quad$ The Expanded Public Works Programme (EPWP) aims to relieve poverty by creating short-term jobs, provide experience and training to previously unemployed persons, and provide access to further employment.

- As was indicated in section 2, the social insurance and social assistance components of the social security system provide protection against risks of income loss due to various contingencies.

- Human capital investments in health care, education and training enhance productivity and facilitate participation in the economy.

- A "social wage" consisting of basic services and other non-financial transfers provides subsidised housing and access to water, electricity, refuse removal and sanitation, including a raft of minimum free basic services for vulnerable groups to prevent non-access to such services because of inability to pay.

- $\quad$ Programmes that facilitate access to assets (especially housing, land and capital) aim to improve the economic and social security of poor households and to provide them with bases for longer-term involvement in the economy.

The social assistance system plays a very specific role within this gamut of anti-poverty interventions, namely to provide assistance to needy groups who are not economically active (the disabled and poor children and elderly individuals). The draft discussion document on an anti-poverty strategy for South Africa released in October 2008 confirmed the importance of this role: ${ }^{17}$

As a country we have done relatively well in terms of providing social assistance, which research evidence shows plays a significant role in alleviating poverty. The provision of social grants will need to continue, particularly for the vulnerable groups such as people with disabilities, the aged and children. (The Presidency, 2008: 16)

The document nonetheless reiterated that the promotion of opportunities remained the primary focus of anti-poverty policy:

As we go forward, we need to strengthen our resolve to reduce the incidence of poverty as well as to prevent intergenerational transmission of poverty within households and communities... Key to this resolve is creating and increasing economic opportunities and facilitating access to these. Unemployment and/or the absence of earned income are the major causes of poverty. Our efforts should be focused on ensuring that as a country we create economic opportunities that will ensure the promotion of self-sufficiency. (The Presidency, 2008: 16, emphasis in the original)

Several recent policy developments have confirmed the Government's focus on the promotion of opportunities as a strategy for reducing poverty. Most notable was the announcement of two important interventions aimed at job creation, namely Phase II of the Expanded Public Works Programme and a youth-targeted wage subsidy scheme ( $c f$. section 4.3). At the same time, the Government's resolve to continue to restrict

${ }^{17}$ As yet, the initial discussion document has not been followed by further drafts or a final document. 
assistance to economically inactive persons has been confirmed by the refusal to introduce a universal income grant despite pressure by sections of civil society and endorsement of such a grant in 2002 by the Committee of Inquiry into a Comprehensive Social Security System (the Taylor Committee). ${ }^{18}$

Government interventions to combat poverty include outlays on goods and services (e.g. expenditures on the provision of education, health care, social grants, housing and municipal services such as water and electricity) and regulatory measures (e.g. the Broad-Based Black Economic Empowerment and employment equity initiatives and labour legislation). Ideally, assessment of the role of the social grants system should be undertaken against the backdrop of the effects of all such interventions. Quantification of the impact of regulatory measures is notoriously difficult, however, and will not be attempted in this paper. Instead, this section draws on the findings of a study of the incidence of social spending undertaken for the National Treasury (Van der Berg, 2009) to comment on aspects of the poverty-reducing role of social grants in South Africa. The study investigated the incidence of the following social spending categories: school and tertiary education, social grants, hospitals, health clinics, and subsidised housing. The analysis covered 68 percent of consolidated general government expenditure on social services, with the coverage of the individual spending categories as follows: education 84 percent, health services -70 percent, social security - 68 percent, and housing 64 percent. Measured in current-price terms, expenditure on these items amounted to R177 billion in 2006; this constituted 37.5 percent of total consolidated non-interest government spending and more than 10 percent of GDP.

As was indicated in section 2.3, social spending has grown markedly since 1994 . Expressed in constant 2000 Rand values, expenditures on the items included in the study nearly doubled from R67.7 billion in 1995 to R133.6 billion in 2006. Growth in social spending was particularly rapid from 2000 to 2006, buoyed by robust economic and government revenue growth. During this period, the aggregate growth rates of the individual social spending categories ranged from 127 percent (social grants) to 15 percent (tertiary education). Outlays on social grants increased from 20 percent of the social spending items included in the study in 2000 to 30 percent in 2006 and overtook spending on public hospitals as the second largest programme after school education. Growth in social spending outstripped population growth to such an extent that real per capita social spending increased by 21 percent from R1 643 in 1995 to R1 987 in 2000 and by a further 42 percent to R2 822 in 2006.

\footnotetext{
18 The campaign for the adoption of a universal income grant system has revolved around calls for a basic income grant (BIG) of R100 per month to all South Africans, irrespective of age and economic status. (The equivalent of a monthly grant of R100 in 2002 in 2009 would have been one of R307.) The Government has never responded in detail to the arguments of the Taylor Committee and other proponents of a universal income grant, but remarks by ministers and officials and press statements indicated that its opposition to the introduction of a BIG system resulted from concern about the affordability of such an intervention and the danger of creating an unhealthy dependency on welfare payments among the poor (cf. Coleman, 2003). Coleman (2003: 22, 23) suggested that fears within Government regarding the affordability of a BIG system may well have been grounded in broader and longer-term considerations: "... one gets the impression that the real concern is less about whether the fiscus would be able to afford it; and more about the implications of giving in to what is seen as 'populist demands'. First, that it would open up the government (or future governments) to pressure to increase the amount of the grant, and that costs could spiral out of control... Second, there seems to be a fear that agreeing to a BIG would open the floodgates for other major new areas of expenditure."
} 
Apart from growth in amounts expended, the poverty impact of social spending was enhanced further by improved targeting. This is confirmed by changes in concentration ratios. Related to Gini coefficients, concentration ratios are measures that assume positive values when spending programmes favour the rich, zero when spending is completely evenly distributed and negative values when spending programmes favour the poor. The concentration ratio for all social spending items included in the study improved from -0.112 in 2000 to -0.152 in 2006 (cf. Table 4) - a considerable improvement to a level that indicates extremely good targeting of the poor. ${ }^{19}$ Over the same period, the portion of such social spending benefitting the poorest 40 percent of the population increased from 47.1 percent to 50.1 percent. Concentration ratios as well as the benefit shares of the poorest 40 percent indicated that social grants were the best targeted of all social spending programmes. ${ }^{20}$ These numbers testified to the effectiveness of the means tests used to determine eligibility for social grants as tools to prevent errors of inclusion (i.e. leakage of social assistance funds to the non-poor). ${ }^{21}$

\section{Table 4}

\section{Indicators of the targeting of social spending in South Africa (2000 and 2006)}

\begin{tabular}{|lcccr|}
\hline Spending category & \multicolumn{3}{c}{ Concentration ratios } & Benefit shares poorest $40 \%$ \\
& 2000 & 2006 & 2000 & 2006 \\
\hline School education & -0.121 & -0.128 & 48.7 & 49.1 \\
Tertiary education & 0.528 & 0.641 & 7.2 & 3.7 \\
Social grants & -0.371 & -0.359 & - & - \\
$\quad$ Child support grants & -0.247 & -0.318 & 57.3 & 61.7 \\
$\quad$ Disability grants & -0.291 & -0.288 & 60.0 & 58.5 \\
$\quad$ Old-age pensions & -0.412 & -0.436 & 69.9 & 70.2 \\
Health & -0.118 & -0.137 & - & - \\
$\quad$ Public clinics & -0.177 & -0.257 & 50.0 & 57.3 \\
$\quad$ Public hospitals & -0.105 & -0.103 & 43.2 & 44.6 \\
Housing & 0.160 & 0.070 & 21.3 & 23.9 \\
\hline All social spending & -0.112 & -0.152 & 47.1 & 50.1 \\
\hline
\end{tabular}

Source: Van der Berg (2009: 14, 27)

The study also showed that social spending had a significant and growing redistributive impact in South Africa. The last columns in Figure 4 confirm two trends highlighted earlier, namely that social spending increased substantially in real per capita terms

\footnotetext{
19 Some of the concentration ratios for 2006 (e.g. those for school education, public hospitals and public clinics) are particularly impressive compared to those for more than 30 developing countries reported by Yaqub (1999). A notable exception is the ratio for tertiary education. See Van der Berg (2009: 13).

${ }^{20}$ For a discussion of the factors influencing the targeting of the various social spending programmes, see Van der Berg (2009: 14-17).

21 These benefits of means testing came at the expense of higher administrative costs, the risk of errors of exclusion, and possible perverse incentive effects. For an assessment of targeting and means testing in South Africa, see Samson, MacQuene, Van Niekerk, Kaniki, Kallmann and Williams (2007).
} 
between 1995 and 2006 and that the largest part of this increase occurred after 2000 . Furthermore, the figure shows that gains in social benefits were recorded right across the income distribution, but the gains for the poor were particularly large. An important reason for this was the rapid growth of the particularly well-targeted social grants spending. In real terms, per capita social spending for the poorest 40 percent of the population increased more than two-and-a-half fold over eleven years, from R1 373 in 1995 to R2 329 in 2000 and R3 532 in 2006 (all in 2000 Rand values). This reflected both the aggregate growth of social spending and improved targeting. The increase of more than R1 200 per person for the poorest 40 percent of the population since 2000 was almost three times as large as for the richest 20 percent.

Figure 4

Real per capita social spending benefits by income quintiles

(2000 Rand values; 1995, 2000 and 2006)

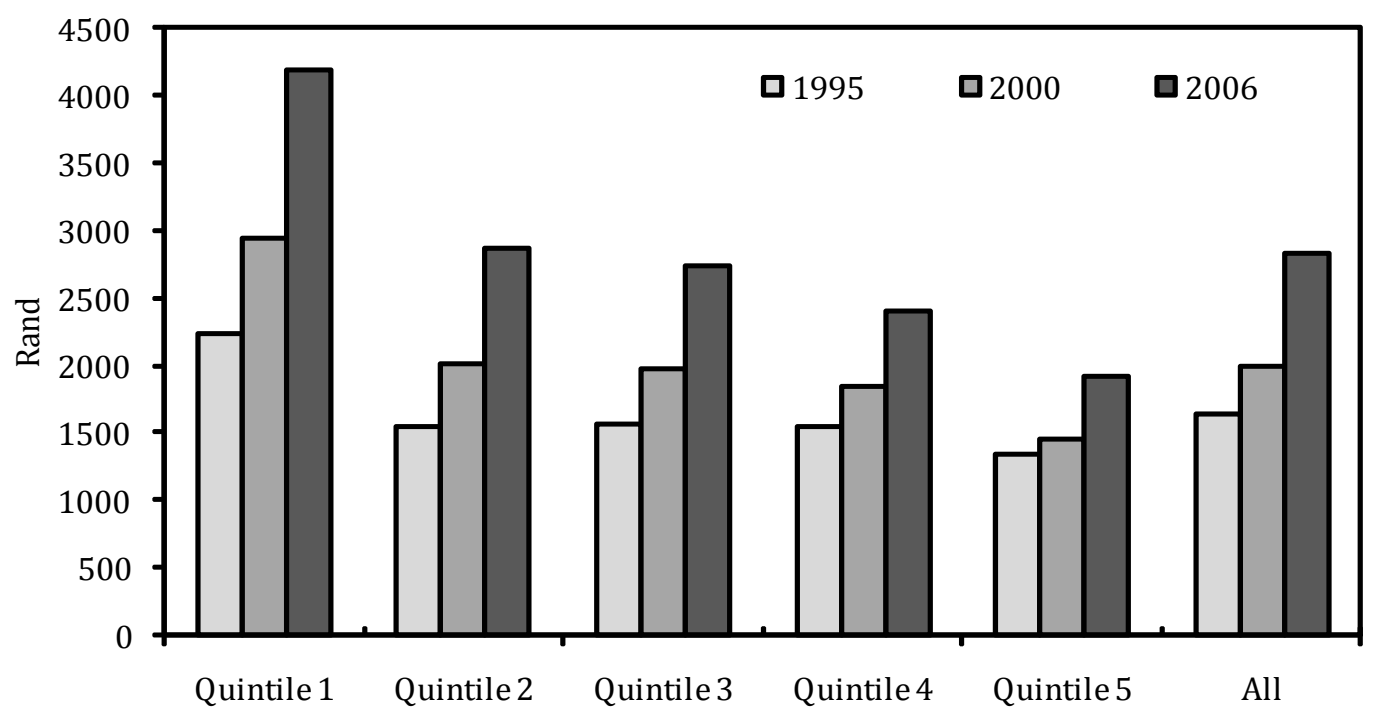

Source: Van der Berg (2009: 20)

Table 5 provides rough estimates of the extent of redistribution through fiscal processes in 1995, 2000 and 2006. For each year, the table shows Gini coefficients for pre-fiscal incomes or expenditures (excluding grants), incomes including social spending benefits, and incomes including social spending benefits minus taxes paid. The comparability of the three underlying income distributions is subject to some uncertainty, and the important numbers therefore are the impact of fiscal processes on the Gini coefficients in specific years and how this has evolved over time. ${ }^{22}$ In 2006, the Gini coefficient for pre-transfer income was 0.69 , but it dropped to 0.52 for income plus benefits and to 0.47 after taxes had also been subtracted. Furthermore, the comparison with earlier years suggest that the budget has become more redistributive over time, with the mitigating impact of fiscal processes on the Gini coefficient increasing from 0.138 in

22 The Gini coefficient is a well-known summary indicator of the distribution of income ranging from 0 (perfect equality) to 1 (perfect inequality). It should be noted also that the coefficients in table 5 are not conventional Gini coefficients for all income; as such, they are not comparable to published Gini coefficients for other countries. 
1995 to 0.180 in 2000 and 0.223 in 2006 . Three conclusions regarding the impact of the budget on the distribution of income follow:

- $\quad$ The South African fiscal process was highly redistributive.

- $\quad$ Social spending had an especially large mitigating impact on income inequality, reducing the estimated Gini coefficients significantly more than what the progressive income tax system did.

- Income inequality remained extremely large even after the effects of all redistributive taxes and social spending programmes had been taken into consideration. This emphasised the limits of fiscal redistribution and the need for a reduction of market-generated income inequality. The latter requires a combination of human capital enhancement and economic growth.

Table 5

Estimates of fiscal redistribution in South Africa (1995, 2000 and 2006)

\begin{tabular}{|lccr|}
\hline & \multicolumn{3}{c|}{ Gini coefficients } \\
& 1995 & 2000 & 2006 \\
\hline A Income/expenditure (excluding grants) & 0.666 & 0.707 & 0.690 \\
B Income plus benefits & 0.578 & 0.576 & 0.523 \\
C Income plus benefits less taxes & 0.528 & 0.527 & 0.467 \\
\hline Effects of the fiscal process $(A-C)$ & -0.138 & -0.180 & -0.223 \\
\hline
\end{tabular}

Source: Van der Berg (2009: 24)

This study also set out to investigate the redistributive impact of the provision of free basic municipal services (water and electricity). In the provision of such services, the mechanism for assisting the poor is cross-subsidisation within municipal boundaries. Unfortunately, this part of the study could not be completed successfully because suitably disaggregated data for determining the impact of free basic services on the positions of the poor and the non-poor were not available. ${ }^{23}$

The findings of the fiscal incidence study highlighted important aspects of the role of the social assistance system in anti-poverty policy in South Africa. The social grants system clearly is a component of a wide-ranging suite of public expenditure programmes aimed at redistributing income and fighting poverty. Benefit incidence analysis suggests that these programmes generally are quite effective at transferring resources to the poor. The social grants system is a salient element of this suite of interventions for at least three reasons. The first is its size: as was indicated earlier, outlays on social grants now form more than one-third of government social spending, making it the second largest component of such spending after education. Second, social grants programmes are particularly effective instruments for ensuring that resources reach the poor, being the best targeted of all social spending categories. Third, the social assistance system is the main cash-transfer component of poverty-focused public spending programmes in South Africa. By providing cash to individuals who are incapable of earning an

${ }^{23}$ For a discussion of the deficiencies of existing data sources, see Essop and Moses (2009). 
independent living (e.g. the disabled and poor children and elderly persons), the social grants schemes complement anti-poverty interventions which build human capital (e.g. provision of education and health services) and meet other basic needs (e.g. housing, water and electricity subsidies).

\subsection{The effectiveness of the South African social assistance system}

This section presents evidence on three questions relating to the effectiveness of the South African social grants system. First, what is the impact of social grants on the incomes of poor households (section 3.2.1)? Second, for what purposes do poor households use social grant income (section 3.2.2)? Third, does the social grants system give rise to widespread unintended effects of an undesirable nature (section 3.2.3)?

\subsubsection{Social grants and the incomes of poor households}

Social grants have become an increasingly common and important source of income for poor South Africans during the past ten to fifteen years. Table 6 highlights that the proportions of households in the poorest four quintiles who reported receiving income from grants increased markedly between 1997 and 2006; in the period from 2002 until 2006, similar increases were evident in the proportions of households in the poorest two quintiles who indicated that grants were their major source of income.

Table 6

Percentages of households reporting income from grants

\begin{tabular}{|l|rrr|rr|}
\hline \multirow{2}{*}{ Quintile } & \multicolumn{3}{|c|}{ Any income } & \multicolumn{2}{c|}{ Main source of income } \\
\hline 1 & 1997 & 2002 & 2006 & 2002 & 2006 \\
2 & 15.9 & 32.0 & 69.4 & 16.1 & 47.7 \\
3 & 54.0 & 55.8 & 69.9 & 31.4 & 51.0 \\
4 & 46.7 & 51.6 & 69.4 & 31.1 & 34.5 \\
5 & 33.8 & 33.2 & 45.4 & 18.1 & 16.0 \\
\hline All & 14.0 & 11.3 & 12.0 & 4.4 & 2.5 \\
\hline
\end{tabular}

Source: Leibbrandt, Woolard, Finn and Argent (2010: 61)

Figure 5 shows that poor households generally lack access to adequate wage income and therefore depend heavily on grant income. ${ }^{24}$ In 2008, labour-market earnings constituted more than 80 percent of the total incomes of each of the three richest deciles, but only 18.7 percent of the total income of the poorest decile. Grant income was an insignificant source of income for the rich - the income shares of grants for deciles 8,9 and 10 amounted to 6.8 percent, 2.6 percent and 0.4 percent, respectively but dominated the cash incomes of the poor. Thus, in the four poorest deciles, the income shares of social grants ranged from 48.3 percent (decile 4) to 72.7 percent

24 The figure is based on 2008 data from the National Income Dynamics Study (NIDS), as reported by Leibbrandt, Woolard, Finn and Argent (2010). 
(decile 1). Van der Berg (2009: 27, 29) estimated that the three largest grant programmes (the old-age pension, the child support grant and the disability grant) more than doubled the income share of the two poorest quintiles in 2006 from 3.3 percent of total pre-transfer income to 7.6 percent of income including grants.

\section{Figure 5}

Labour market and grant incomes by deciles (2008)

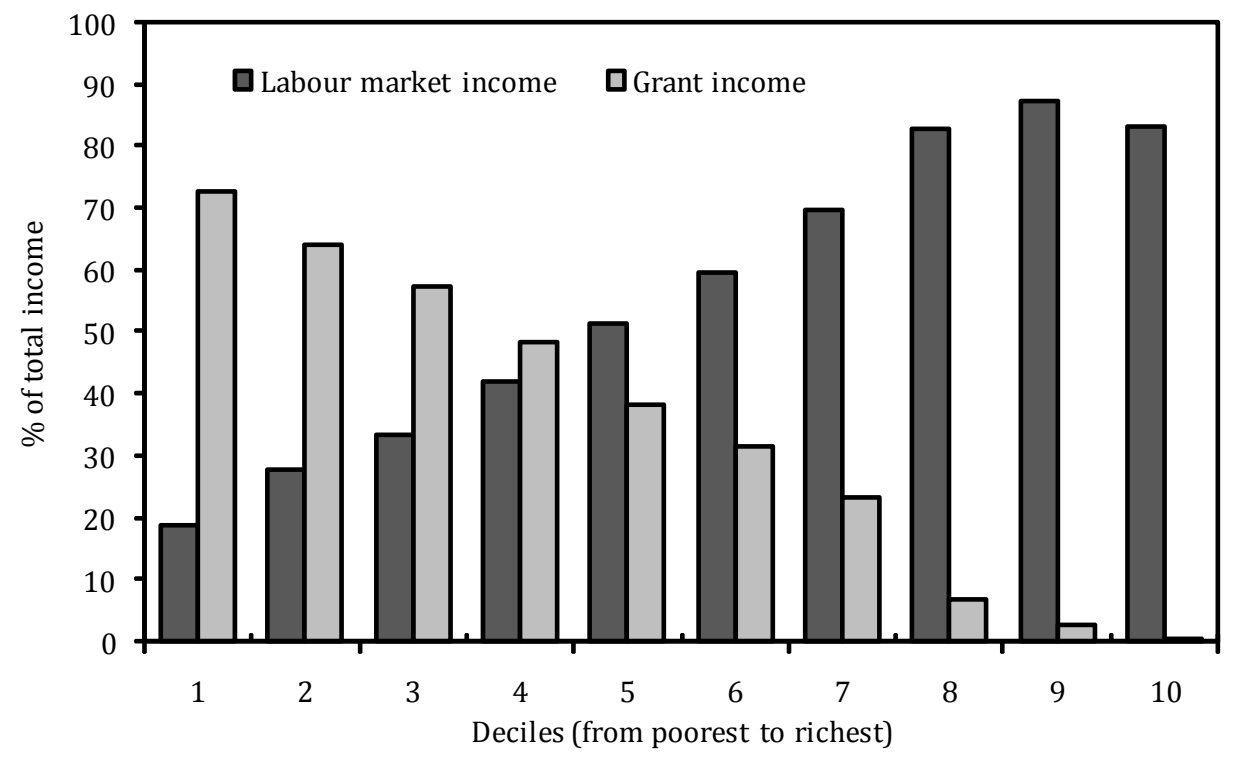

Source: Leibbrandt, Woolard, Finn and Argent (2010: 78)

To obtain a rough indication of the mitigating effect of social grants on poverty, some studies (e.g. Woolard, 2003; Armstrong, Lekezwa and Siebrits, 2008; Armstrong \& Burger, 2009) have compared the actual incidence of poverty to the incidence that would have obtained if all households had earned zero income from social grants. Such exercises are indicative only - they obviously are sensitive to the choice of a poverty line and rest on the very strong assumption that the availability or otherwise of social grants has no impact whatsoever on the behaviour of households in terms of labour supply, household formation patterns, et cetera - but nonetheless suggest that social grants markedly increase the incomes of very poor households in South Africa. ${ }^{25}$

Table 7 summarises findings of such an analysis of data from Statistics South Africa's Income and Expenditure Survey 2005 (Armstrong and Burger, 2009). The table shows the impact of social grants at the three experimental poverty lines used by Statistics South Africa: annual per capita incomes of R2 532, R3 864 and R7 116. At a poverty line of R2 532 per person per annum, social grants reduced the headcount poverty rate from 45.5 percent to 31.5 percent, that is, by 13.9 percentage points or 30.5 percent. The reality that the estimated impact on poverty was so much smaller at higher poverty lines confirmed the effectiveness of the grants for targeting those experiencing relatively severe poverty. Additional (albeit indirect) evidence of the poverty-reducing impact of social grants includes the drop in the headcount poverty rate from 50 percent

25 Other studies of the effects of specific grants (e.g. Case and Deaton, 1998; Barrientos, 2003) and the social grants system as a whole (e.g. Samson, Lee, Ndlebe, MacQuene, Van Niekerk, Gandhi, Harigaya and Abrahams, 2004) reached the same conclusion. 
in 1993 and a peak of 53 percent in 1996 to 39 percent in 2008 (Van der Berg, Louw and Yu, 2008: 68-70; The Presidency, 2009: 26) ${ }^{26}$ and the decrease in the portion of children who had gone hungry in the previous year from 31 percent in 2002 to 16 percent in 2006 (Van der Berg, Louw and Du Toit, 2009: 25). Other studies (e.g. Leibbrandt et al., 2010) have also argued that the expansion of the social assistance system has been a major driver of the fall in headcount poverty rates after 2000 .

Table 7

Effects of social grants on poverty

\begin{tabular}{|lrrr|}
\hline & \multicolumn{3}{c|}{ Poverty rate (at annual poverty lines) } \\
& R2 532 & R3 864 & R7 116 \\
\hline Headcount ratio excluding grant income & 45.5 & 55.0 & 67.6 \\
Headcount ratio inclusive of grant income & 31.6 & 47.3 & 65.3 \\
Absolute change & 13.9 & 7.7 & 2.3 \\
Percentage change & 30.5 & 14.0 & 3.4 \\
\hline
\end{tabular}

Source: Armstrong and Burger (2009: 14)

\subsubsection{Developmental effects}

Providing well-targeted cash transfers to the poor is at best a necessary condition for reducing poverty: the actual impact of such transfers depends crucially on how poor people use the money. The most obvious threat to the poverty-mitigating potential of cash transfers is outright squandering of money on luxuries and so-called "sin goods" a risk that has spawned a well-known (though far from conclusive) argument for the superiority of in-kind transfers over cash grants. Cognisance also should be taken of the distinction between the "livelihood protection" and "livelihood promotion" effects of anti-poverty interventions ( $c f$. Devereux, 2002a: 661, 662). Livelihood protection effects have to do with consumption smoothing and maintenance of minimum living standards, while livelihood promotion effects involve sustainable poverty reduction through promotion of higher living standards in the longer term. Cash transfers traditionally were regarded as mechanisms for protecting livelihoods (e.g. during economic crises), but more recent research has highlighted that such transfers can contribute to the achievement of sustainable poverty reduction if the recipients invest in incomegenerating activities, education, social networks and the acquisition of productive assets (Devereux, 2002a). South Africa's social grants currently are not structured as livelihood-promoting interventions, being targeted at needy individuals who do not form part of the economically active population. However, the largest group of beneficiaries are poor children, who receive child support grants or live in multigeneration households sustained by social pensions. These children will eventually join the labour force and the grants could contribute to their future productivity to the extent that it is invested in their sustenance and education. This subsection discusses the findings of studies that have explored the impact of grant income on the spending

\footnotetext{
${ }^{26}$ Calculated from the All Media and Products Survey dataset, these poverty rates show the portions of the population that lived on less than R388 per person per month in constant 2008 Rands. For more information on the dataset, see Van der Berg et al. (2008: 63-64).
} 
patterns of recipient households in South Africa, with particular emphasis on the nutrition and school attendance of children.

Du Toit and Neves (2009) have pointed out that at least two factors complicate efforts to uncover relationships between grant income and household spending patterns. The first (and best known) is that the fungibility of money makes it particularly difficult to establish how grant income is actually used. A less appreciated but equally important factor is that decisions on the use of grant income take place within networks of informal social protection characterised by "complex monetary and non-monetary debts, obligations, exchanges, claims, histories and links" (Du Toit and Neves, 2009: 20). These sets of influences on the spending of grant money tend to be fluid and householdspecific, and generalisation of survey results therefore is hazardous.

Be that as it may, no evidence of large-scale squandering of grant money has come to light yet, and several studies have found that grant receipts boost the food spending of beneficiaries. The responses to a survey by De Koker, De Waal and Vorster (2006: 483, 639-673) indicated that food is the first item on which about 75 percent of beneficiaries spent their grant money, and 50 to 60 percent (depending on the grant type) of recipients spent most of their grant money on food. ${ }^{27}$ Another survey found that households that received child support grants spent 55 percent of their incomes on food, compared to 53 percent in households that were eligible for but did not receive such grants (CASE, 2008: 31). ${ }^{28}$ Similarly, according to Samson, Lee, Ndlebe, MacQuene, Van Niekerk, Gandhi, Harigaya and Abrahams (2004: 75-77), households who receive grants spent relatively more on basic necessities (food, fuel, housing, and household operations) and relatively less on medical care, debt service and tobacco than households who did not receive grants. ${ }^{29}$

Research has highlighted the nutritional benefits to children of increases in food spending associated with receipt of child support grants and social pensions. Using children's height-for-age ratios as ex post indicators of nutritional inputs, Aguero, Carter and Woolard (2007) found that children in KwaZulu-Natal benefitted significantly from receiving child support grants during the first 36 months of their lives. Using data from the KwaZulu-Natal Income Dynamics Study, Yamauchi (2005) found that nutritionrelated improvements in child health markedly lowered the age for starting school, increased the grade reached, and reduced grade repetition at the early stage of schooling. According to Williams (2007: 55-59), each grant received by a household markedly reduced the probability that any child in that household goes hungry.

With regard to old-age pensions, it emerged that the gender of the recipient influenced the nutrition and health-status effects of social grants. Duflo (2003) studied trends in the weight-for-height ratios of African children following the large increases in social pensions during the late 1980s and early 1990s. On balance, she found that the weightfor-height ratios of girls living in households with female pension recipients increased,

\footnotetext{
27 This study was undertaken by the Department of Sociology and Social Anthropology at Stellenbosch University for the Department of Social Development.

28 The survey was undertaken by the Community Agency for Social Enquiry (CASE) for the Department of Social Development, the South African Social Security Agency and the United Nations Children's Fund.

29 This study used data generated by the October 2000 Income and Expenditure Survey (IES), linked to data from the September 2000 Labour Force Survey and earlier October Household Surveys.
} 
while no increases were discernable in the same ratios of boys or girls living in households with male pension recipients. Samson et al. (2004: 82) and Lund (2006) also found that the nutrition of families with female pension recipients was more likely to improve than those with male recipients.

The evidence suggested that receipt of child support grants and old-age pensions encouraged school attendance among child support grant recipients and children living with pensioners (Case, Hosegood and Lund, 2005; Budlender and Woolard, 2006; Leibbrandt et al., 2010: 62-63). ${ }^{30}$ On the whole, the positive effects on attendance were small in absolute terms - a reflection of the relatively high school enrolment and attendance rates in South Africa (cf. section 4.4.2) - but implied significant reductions in non-attendance (Budlender and Woolard, 2006: viii).

\subsubsection{Incentive effects}

\section{The labour market}

As was indicated earlier, the vehicle for the provision of unemployment benefits to ablebodied South Africans is the Unemployment Insurance Fund - a contribution-based social insurance institution. People with disabilities are the only members of the working-age population who qualify for grants (subject to the means test). This, however, does not mean that the South African social assistance system has no impact on labour-market participation whatsoever. Research has shown that the grant system has important labour-market ramifications, but these do not arise primarily as a result of the mechanism normally emphasised by economic theory, namely distortion of the relative prices of work and leisure. Responses to the Human Sciences Research Council's South African Social Attitudes Survey showed that poor South Africans generally prefer labour-market income to the currently available grants: in 2006, 67.1 percent of those not working for pay (including 75.3 percent of the unemployed) indicated that they do not regard themselves as better off claiming grants than working (Noble, Ntshongwana and Surender, 2008: 15-16). Instead, the grants system seems to influence the supply of labour through direct and induced effects on retirement decisions, household formation and job search activities.

Directs effects have to do with the incentives faced by the actual recipients of grants. The means test discourages elderly people of limited means from working after reaching the age of eligibility by imposing an effective marginal tax rate of 50 percent on non-pension incomes exceeding R606 per month (R7 272 per annum). ${ }^{31}$ A similar poverty trap arises in the case of the disability grant, which is subject to the same means test. In the South African context, this discouraging effect of the means tests is likely to be exacerbated by the exceptionally high unemployment rate and other labour-market disadvantages faced by elderly and disabled South Africans (many members of these

\footnotetext{
30 The only exception to this pattern was a survey-based study of the impact of the child support grant; which reported "... no discernable difference in levels of school attendance between children aged seven to 13 years who are receiving the grant and those who are not" (CASE, 2008: 39).

31 The formula $\mathrm{D}=1.3 \mathrm{~A}-0.5 \mathrm{~B}$ (with $\mathrm{D}$ the monthly pension payable, $\mathrm{A}$ the maximum monthly pension payable, and $\mathrm{B}$ the monthly private income of the beneficiary) implies that the maximum monthly pension of R1 010 is paid to recipients with private incomes of R606 per month or less. The monthly value of the pension decreases by 50c for every R1 of private income available to the recipient above R606 per month and falls to zero when private income reaches R2 426 per month.
} 
groups have limited skills and reside in rural areas where job opportunities are scarce). An additional factor affecting people with disabilities is that the available job opportunities tend to be temporary and low-paid (Lund, 1998: 12). The resulting small differential between the disability grant and the available market wages means that there is little incentive for a person with a disability to take up paid work. ${ }^{32}$

Several empirical studies have explored the induced labour-market effects of elements of the South African social assistance system, that is, effects on persons other than the actual recipients. There are the strong indications that the social pension has become a major source of support for unemployed South Africans of working age, especially in the rural areas ( $c f$. Case and Deaton, 1998; Keller, 2004; Klasen and Woolard, 2008). Unemployed youths and younger adults often delay forming new households or return to their parents or relatives to share in the pension income of the elderly. Such attachment to households with pension recipients apparently affects labour-market participation in two ways. Some individuals stop looking for work when they join such households, often because they are located in rural areas where job opportunities are scarce (Klasen and Woolard, 2008: 5).33 Researchers who have included migrant absentees in their definitions of households, however, found that access to pension income stimulates labour-market participation by enabling some household members to undertake job search away from home ( $c f$. Posel, Fairburn and Lund, 2006; Sienaert, 2008). Such positive effects are particularly strong for women.

Williams (2007) found that receipt of child-support grants positively influenced labourforce participation by caregivers, but apparently did not affect their search behaviour or actual employment:

...receiving a CSG may give a mother some income stability and alleviate [sic] her enough from domestic duties and immediate subsistence needs that she is capable of holding a job. This would account for an increase in broad participation. However, if the means test income threshold is likely to be a binding constraint for her, this willingness to work may not translate immediately into active job search and employment - she may be passively network-searching for an employment opportunity that compensates her enough for the loss of her CSG.

Major labour-supply effects, however, are unlikely in view of the relatively small value of the child support grant ( $c f$. CASE, 2008: 27). This was corroborated by another finding of the South African Social Attitudes Survey: 70.6 percent of the respondents disagreed or strongly disagreed with the proposition that the child support grant was too high and discouraged job-seeking (Noble, Ntshongwana and Surender, 2008: 15).

\section{Saving}

As was indicated above, the means test imposes an onerous effective marginal tax rate of 50 percent on non-pension incomes exceeding R606 per month (R7 272 per annum).

\footnotetext{
32 Johannsmeier (2007: 62) pointed out that this is especially true as far as casual and temporary jobs are concerned.

33 Bertrand, Mullainathan and Miller (2003) also found that the presence in households of pension recipients was correlated with reduced labour supply by household members of working age.
} 
Hence, the means-tested nature of the social old-age pension reduces the incentive for low-income earners to save for retirement (National Treasury, 2004b: 11). The means test sometimes penalises lower-income workers with inadequate occupational pensions to such an extent that their retirement incomes (i.e. the sum of the occupational and social pensions) are only slightly higher than those of others who have contributed for much shorter periods. The actual impact of this disincentive on the savings decisions of lower-income workers behaviour has not been established empirically yet.

\section{Fertility}

Public discourse has been indicative of concern about the possibility that the availability of child support grants has been encouraging needy women (especially teenagers) to have more children. Empirical evidence on this issue remains scant, but Makiwane, Desmond, Richter and Udjo (2006) argued that there are least three reasons for suspecting that the introduction of the child support grant has not had a major impact on the prevalence of teenage pregnancy in South Africa:

- The incidence of teenage pregnancy has increased in all sections of society over time, including those that are not eligible for means-tested child support grants. This suggests that forces other than the desire to access grants are at work.

- $\quad$ The incidence of teenage pregnancy increased markedly in South Africa during the mid-1990s, but then levelled off around the turn of the millennium. Hence, it does not appear as if the introduction of the child support grant, which occurred in 1998, had a strong positive impact on teenage pregnancy.

- If large numbers of teenagers were falling pregnant to access grants, one would have expected a very high take-up of the child support grant among teenage mothers. Yet this has not been the case. In the period from 1998 to 2006, some 15 percent of babies in South Africa were born to teenage mothers, but teenagers constituted only three percent of the beneficiaries of child support grants.

Incentives matter at the margin; hence, the availability of the grant may have tilted the cost-benefit calculations of some in favour of having more children. In all likelihood, however, a small grant of R250 per month or less would have been a decisive factor in the reproductive decisions of only a relatively small number of people. Given the absence of clear evidence of increases in the incidence of teenage pregnancy or of reductions in the age of first conception since 2000, the introduction of the child support grant probably at most has slightly slowed the ongoing decline in the fertility rate in South Africa compared to what would have happened otherwise.

\section{Health}

The impact of HIV/Aids on prime-aged individuals is such that the household usually foregoes the income of the affected member. HIV/Aids-infected individuals qualify for disability grants when they become physically unable to work, but payment of such grants is terminated if their health status improves sufficiently. Highly Active Antiretroviral Treatment (HAART) usually achieves such restoration of health within six months (Venkataramani, Maughan-Brown, Nattrass and Rugeres, 2009: 2). Nattrass (2006a; 2006b) first pointed out that this policy could give rise to perverse incentives: given the difficulty of finding employment in the labour-surplus South African economy, 
HIV/Aids sufferers may be tempted to avoid or discontinue Highly Active Anti-retroviral Treatment (HAART) in order to remain eligible for disability grants. In a study involving a large sample of the residents of the Khayelitsha Township in Cape Town, Venkataramani et al. (2009) found no evidence of individuals compromising their health in this manner. They did find, however, that losing the disability grant as a result of successful anti-retroviral treatment often subjected individuals and households to sharp decreases in incomes (Venkataramani et al., 2009: 9-10).

\section{REFORM ISSUES AND OPTIONS}

The growth performance of the South African economy has improved markedly from 1994 onwards. The protracted stagnation in per capita income came to an end: real per capita GDP at constant 2000 prices, which had decreased from R21 167 in 1970 to R19 996 in 1993, increased at an average annual rate of 1.67 percent after 1994 to reach R25 897 in 2008 (South African Reserve Bank, 2009: S-149). The poor, however, benefitted to a limited extent only from the accompanying increase in personal incomes. ${ }^{34}$ As was indicated in section 3.2.1, the headcount poverty rate decreased by 14 percentage points from 53 percent in 1996 to 39 percent in 2008, but a significant portion of this drop resulted from the expansion of the social grants system. Moreover, in 2008 fully 39 percent of the South African population still lived on R388 per month or less (cf. Figure 6).

Figure 6

Headcount poverty rates based on AMPS data (1993-2008)

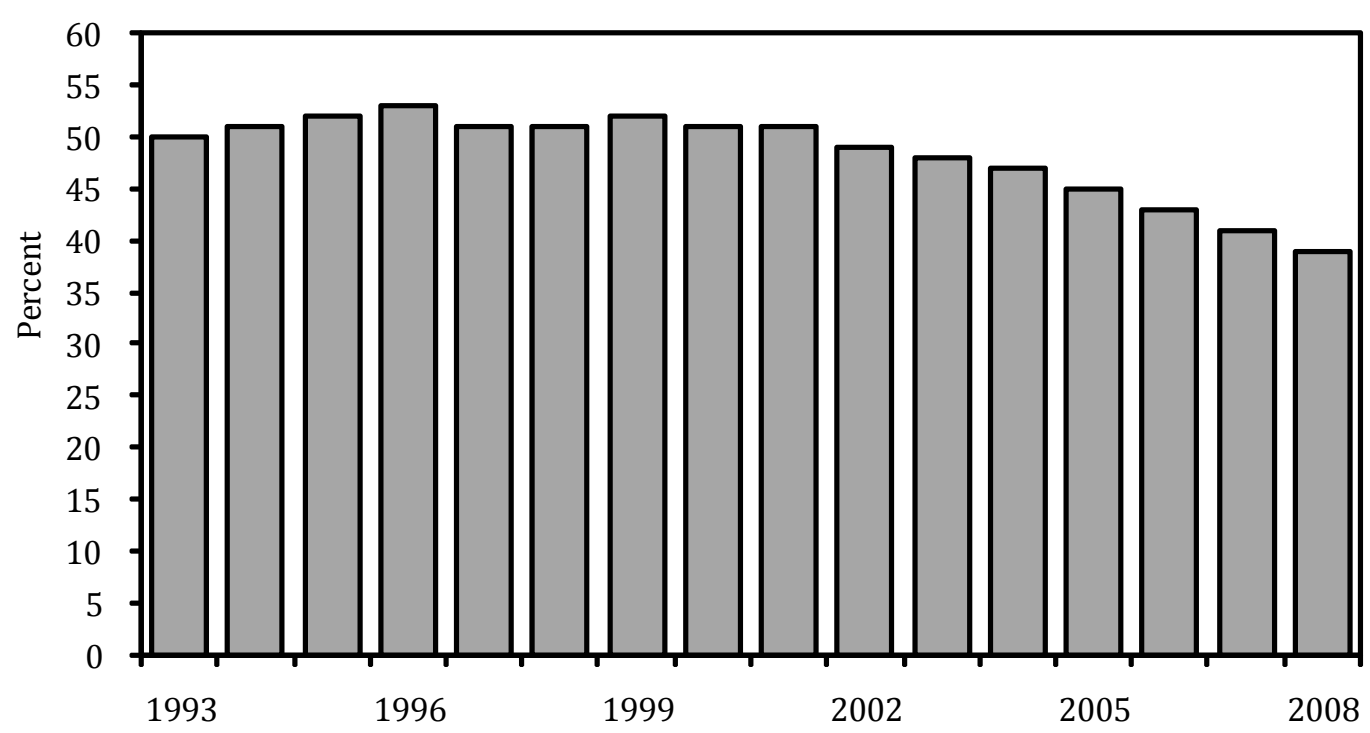

Sources : 1993-2007 - Van der Berg, Louw and Yu (2008: 70); 2008 - The Presidency (2009: 26) Note: Poverty line: R388 per person per month (constant 2008 Rands)

This state of affairs is ample reason for reflection on the future role of the social grants system in anti-poverty policy in South Africa. The remainder of this section provides

\footnotetext{
34 Personal or primary income is the actual value of income received in cash or in kind by individuals and households. Secondary income is primary incomes minus direct taxation plus the value of government services consumed.
} 
such reflection. Section 4.1 discusses the relationship between economic growth and employment creation in South Africa. It shows that job-creating economic growth is crucial for overcoming poverty, but also identifies factors which hamper employment creation and, hence, progress in reducing poverty. Against this background, and with reference to the current fiscal situation and recent policy developments, Section 4.2 comments on the future role of the social grants system in anti-poverty policy in South Africa. This section also briefly discusses the potential of the Expanded Public Works Programme (EPWP) and the recently announced youth wage subsidy schemes as alternatives to further expanding the scope of the social grants system. Sections 4.3 and 4.4 discuss two sets of possible reforms to the social assistance system that are being debated or implemented in South Africa: child-focused conditional cash transfer programmes and so-called "new-style" workfare programmes.

\subsection{Economic growth, job creation and poverty in South Africa}

In developing countries, relatively low per capita incomes limit the scope for reducing poverty by redistributing existing resources. As was emphasised by Bhorat (2004: 944), job-creating economic growth therefore is the primary vehicle for sustainable poverty reduction:

It is the labour market that ultimately lies at the centre of access to income (or lack thereof) in the long run. A well-performing, jobgenerating labour market remains the key long-run mechanism for reducing the poverty and inequality levels in the domestic economy. ${ }^{35}$

The links among economic growth, job creation, unemployment and poverty may seem self-evident, but the experience of the early and mid-1990s cast doubts about their validity in the then South African context. At the time, the South African economy shed jobs while output was expanding (albeit slowly), causing some to fear that the country was facing the bleak prospect of persistent "jobless growth" (cf. Hodge, 2009: 497-498). Such fears, however, proved to be unfounded. The fall in total employment during this period of positive economic growth resulted from sector-specific developments in manufacturing (possibly related to trade liberalisation) and, especially, gold mining (Hodge, 2009: 502). Moreover, 2.5 million new formal-sector and informal-sector jobs were created between September 2001 and September 2008 as economic growth continued and accelerated (The Presidency, 2009: 20).

Using the data depicted in Figure 7, Hodge (2009: 497-498) pointed out that the period of "jobless growth" during the early and mid-1990s represented an aberration: since World War II, employment growth often lagged output growth in South Africa, but negative employment elasticities of economic growth have been rare. Hodge (2009: 497) estimated the long-term average ratio between employment growth and real economic growth as about 0.5 , that is, a 1 percentage point increase in economic growth is associated with half a percentage point increase in employment growth. According to the National Treasury (2010a: 43), the employment elasticity of economic growth reached 0.66 from 2003 to 2008 - a level that compared favourably with estimates for other countries by the International Labour Organisation.

\footnotetext{
${ }^{35}$ As was indicated in section 3.1, this proposition is at the heart of the anti-poverty strategy of the South African Government.
} 
Figure 7

Output and employment growth in South Africa

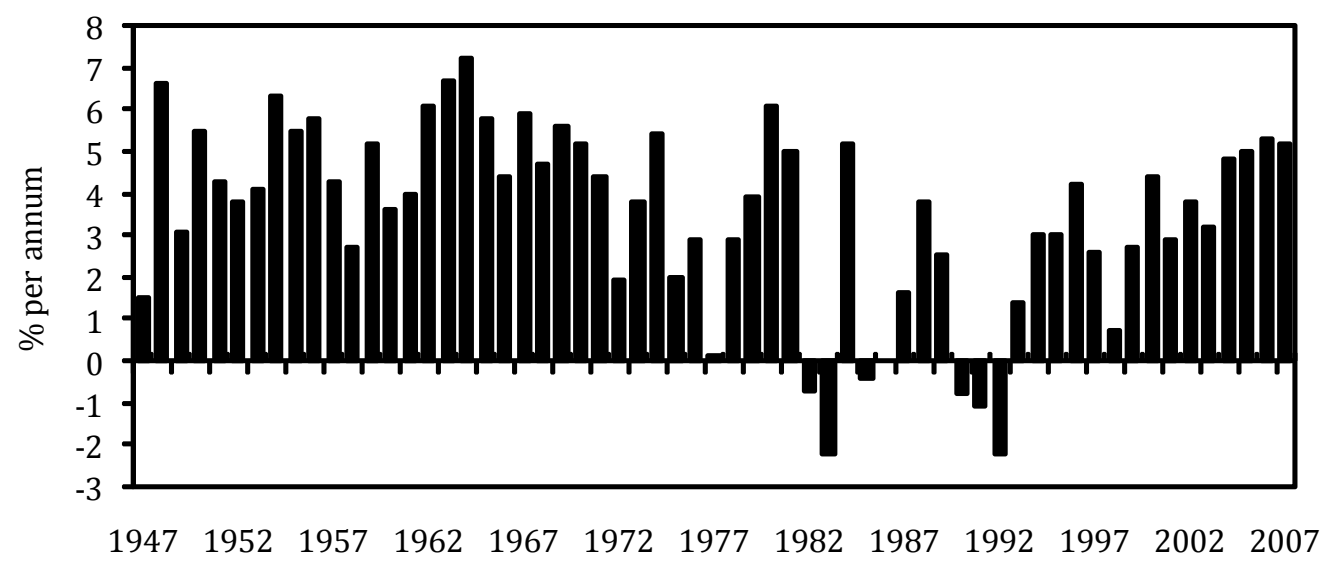

Rate of change in real gross value added at constant 2005 prices

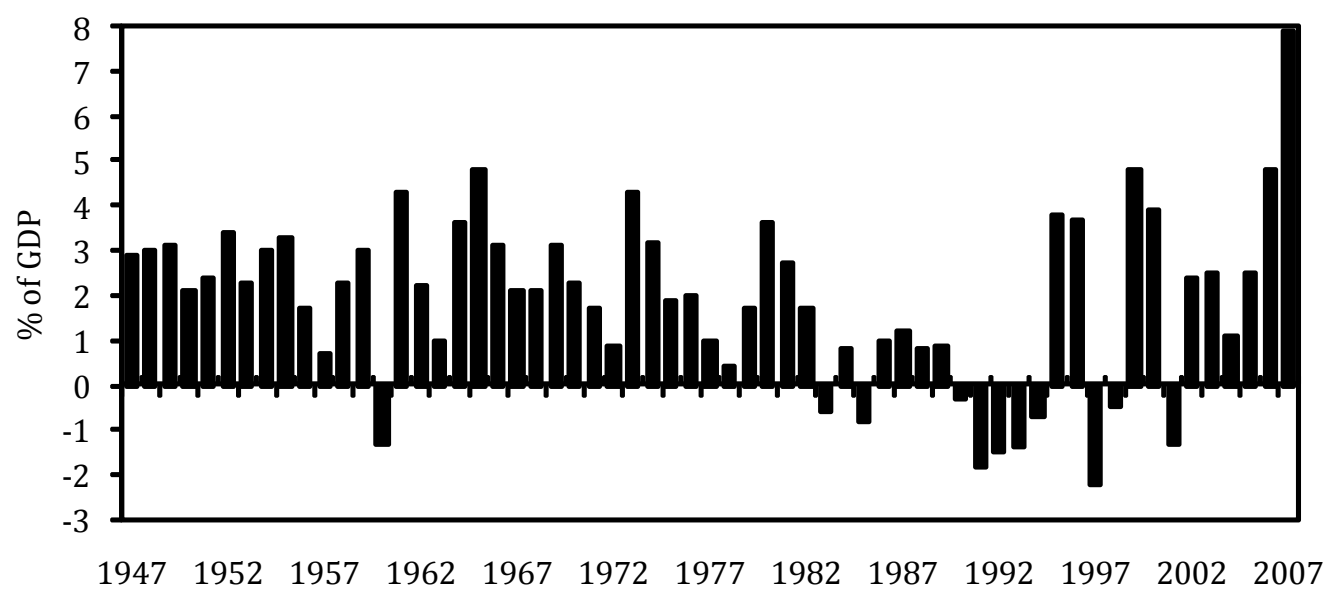

Rate of change in total employment

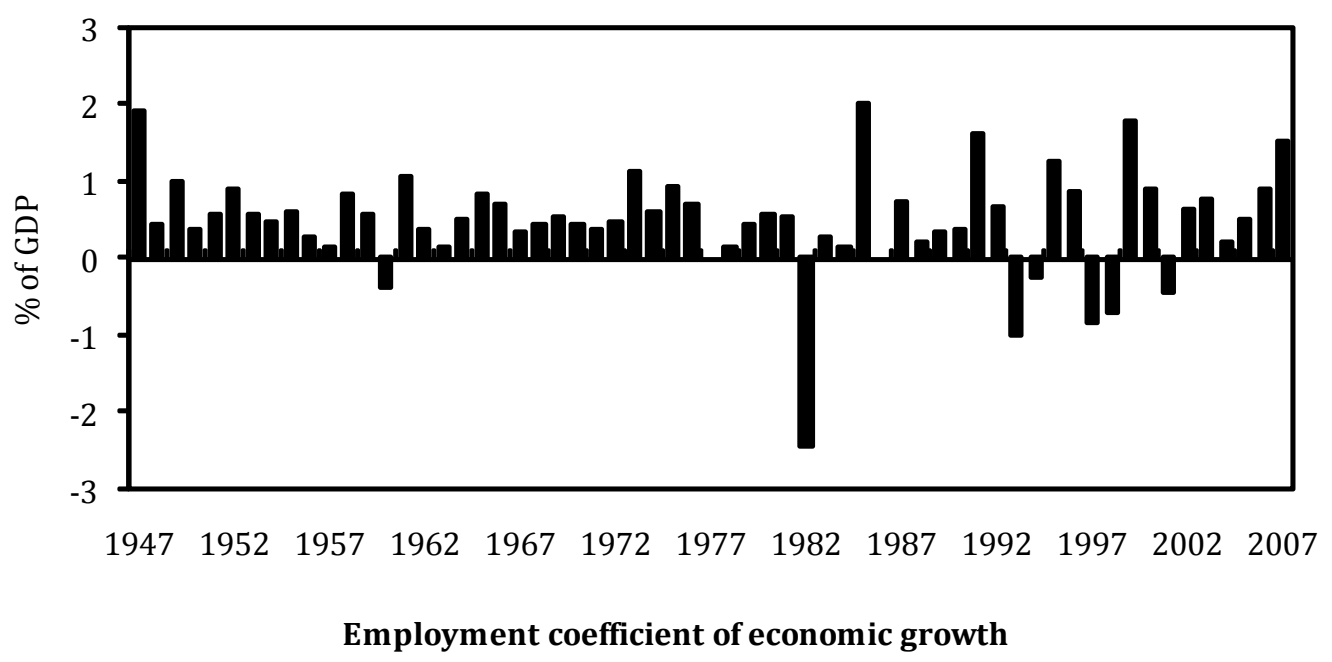

Source: Hodge (2009: 503)

Employment growth during the post-1994 period nonetheless has been inadequate to sharply reduce unemployment and poverty in South Africa. Unemployment was already 
high at the time of democratisation - the 1995 October Household Survey reported narrow and broad unemployment rates of 17.6 percent and 30.8 percent, respectively (Yu, 2008: 32) - and increased further during the second half of the 1990s and the early years of the millennium. ${ }^{36}$ The narrow and broad unemployment rates peaked in March 2003 (at 31.2 percent and 42.5 percent, respectively), and then decreased as economic growth accelerated, reaching lows of 23.0 percent in September 2007 and 30.2 percent in September 2008 (The Presidency, 2009: 21). Job losses resulting from the global financial crisis partially reversed this progress, however, and by the end of 2009 the narrow unemployment rate had risen to 24.3 percent (National Treasury, 2010a: 39).37 International comparisons of unemployment are fraught with problems, but the evidence suggests that these are exceptionally high rates of open unemployment. Before the recent recession, for example, 44 percent of the working-age population in South Africa had jobs, compared to the international average of 60 percent (National Treasury, 2010a: 37-38; cf. also Kingdon and Knight, 2004: 391-392).

Research has suggested that supply-side and demand-side factors have hampered the ability of the South African economy to create enough jobs. On the supply side, South Africa has experienced rapid labour-force growth, especially during the second half of the 1990s (Hodge, 2009: 499-500). ${ }^{38}$ The labour force has expanded much more rapidly than the working-age population (Kingdon and Knight, 2007: 816-819), which implied that labour-force participation rates increased markedly. ${ }^{39}$ Burger and Woolard (2005: 5-8) and Kingdon and Knight (2007: 816-819) ascribed the increase in participation rates - which has been particularly noticeable among African women - to actual and perceived improvements in employment opportunities following the scrapping of apartheid-era restrictions on the mobility of Africans and the introduction of employment-equity legislation, rising education levels, and rapid growth in the number of households because of factors such as changes in household structure and HIV/Aidrelated deaths among households heads.

As was indicated above, inadequate economic growth has been the major demand-side factor that has hampered job creation in South Africa. Furthermore, mismatches between the supply of and the demand for labour have constrained the labour intensity of economic growth. Most notably, the economy has experienced considerable structural change since 1970, with the primary sectors (agriculture and mining) shedding labour and new job opportunities arising in tertiary sectors such as finance, wholesale and retail trade and community, social and personal services (Banerjee, Galiani, Levinsohn, McLaren and Woolard, 2009: 723-724; National Treasury, 2010a: 40). These changes have contributed to an increase in the demand for more skilled

\footnotetext{
36 The narrow unemployment rate (the official unemployment rate in South Africa) is the percentage of the labour force that was without work in the week preceding an interview conducted as part of an official labour-market survey, has taken active steps to look for work and was available for work. The broad unemployment rate is the percentage of the labour force that was without work in the week preceding such an interview and was available for work.

37 Total employment fell by 870000 during 2009 alone (National Treasury, 2010a: 39).

38 Labour-force growth has slowed sharply from 2000 onwards, averaging only 0.7 percent per annum from 2000 to 2007 (Hodge, 2009: 500).

39 Kingdon and Knight (2007: 816-819) pointed out that immigration also contributed to rapid labourforce growth. Much immigration, however, has been informal or illegal and the extent of this contribution is therefore difficult to quantify.
} 
labour accompanied by a fall in the demand for unskilled labour that has markedly worsened the employment prospects of the large unskilled portion of the South African labour force (Burger and Woolard, 2005: 16-18).

Table 8 confirms that the skills composition of employment has shifted from unskilled and semi-skilled to skilled labour since 1995. Only 17.7 percent of the new jobs created from 1995 until 2008 required unskilled workers and by 2008 only 22.8 percent of all jobs were classified as "unskilled". Fully 46.4 percent of the new jobs created between 1995 and 2008 were in the semi-skilled category, but this category's share of all jobs also decreased. By contrast, the portions of all job requiring skilled workers had increased from 21.8 percent in 1995 to 26.1 percent in 2008.

Table 8

The skills composition of employment (1995-2008)

\begin{tabular}{|lrrr|}
\hline Year & Percentages \\
& Unskilled & Semi-skilled & Skilled \\
\hline 1995 & 25.1 & 53.1 & 21.8 \\
2004 & 23.4 & 52.7 & 23.9 \\
2008 & 22.8 & 51.0 & 26.1 \\
Job growth (1995-2008) & 17.7 & 46.4 & 35.9 \\
\hline
\end{tabular}

Source: National Treasury (2010a: 41)

The relationship between labour-market institutions and outcomes is a controversial aspect of the unemployment debate in South Africa. Since 1995, the Government promulgated a series of laws that have substantially changed the complex of labourmarket institutions. ${ }^{40}$ Some economists (e.g. Arora and Ricci, 2005: 25-30) have argued that aspects of this institutional framework - including the laws governing collective bargaining processes and working conditions - have contributed to high unemployment in South Africa by rendering the labour market inflexible. The South African Government long resisted calls for the reform of this framework, having invested much political capital in its establishment. However, the following passage in the 2010 Budget Review (National Treasury, 2010a: 48-49) may have indicated the emergence of greater willingness to consider reforms to this framework:

South Africa has a well-developed labour-market regulatory environment, including effective employment protection legislation. In its 2008 Economic Assessment of South Africa, the Organisation for Economic Cooperation and Development (OECD) indicates that employment protection is broadly in line with international standards and is "relatively flexible". The OECD suggests, however, that the resolution of labour disputes and dismissals is slow and cumbersome, raising the costs and perceived risks to employers. Such difficulties inhibit new hiring, since firms are reluctant to hire inexperienced workers when it is costly

\footnotetext{
40 The most important pieces of legislation were the Labour Relations Act (1995), the Basic Conditions of Employment Act (1997), the Employment Equity Act (1998), and the Skills Development Act (1998).
} 
to dismiss poor performers. It seems likely that improved implementation of labour protection legislation, together with adjustments to regulations where required, would contribute to better outcomes for both employment and industrial development.

Labour-market institutions such as collective bargaining frameworks affect wage determination in various ways. ${ }^{41}$ Wage trends have varied since 1994, with rapid growth in some sectors (e.g. manufacturing, where real wages increased more than 40 percent between 1992 and 2008) and sluggish growth in others (e.g. the informal economy) (National Treasury, 2010a: 42). Data comparability issues have complicated analysis of overall trends in real wages: thus, Burger and Yu (2006) claimed that real wages increased by 4 percent from 1995 until 2005, while Banerjee et al. (2009) estimated a drop of 10 percent for the same period. Consistent with this estimate, Banerjee, Galiani, Levinsohn and Woolard (2006) argued that excessive wage growth was not a strong driver of the increase in unemployment in South Africa between 1995 and 2003. They added, however, that real wages did not fall enough to clear the labour market, partly because of the power of labour unions but also because the required drop was too large to be acceptable politically and socially ( $c f$. Banerjee et al., 2006: 4).

Analysis of the South African labour market has highlighted two additional constraints to overcoming the unemployment problem. First, the legacy of apartheid-era spatial planning (which separated Black job seekers from job opportunities) and residual vestiges of racial discrimination may well undermine the effectiveness of search processes in the labour market (Banerjee et al., 2009: 734). Second, young people seem to experience exceptional difficulty in obtaining their first jobs and are affected particularly harshly by the scarcity of jobs. ${ }^{42}$ Firms apparently put a high premium on work experience when making hiring decisions, possibly as a screening mechanism in an environment where virtually all younger workers now have at least ten years of formal education (Banerjee et al., 2009: 736-737).

Another notable feature of the South African labour market highlighted by Kingdon and Knight (2004: 391-392) is the small size of the informal sector: in contrast to the situation in most developing countries, the informal sector apparently has not expanded rapidly to compensate for the scarcity of formal-sector jobs. ${ }^{43}$ In the fourth quarter of 2009, for example, some 2.1 million workers were active in the non-agricultural informal sector while 5.8 million were either openly unemployed or classified as discouraged work-seekers (Statistics South Africa, 2009a: vi).

\footnotetext{
${ }^{41}$ A well-known example is the centralisation of wage bargaining, in terms of which large firms and labour unions can extend arbitration agreements to all workers in defined bargaining council areas, including those employed by smaller non-unionised firms. Magruder (2010) found that such agreements reduce employment in particular industries by 8 to 13 percent, with small firms affected most.

42 According to the National Treasury (2010a: 51, 42), more than 3 million young people do not work, and fully 73 percent of the unemployed are in the 15-35 age group.

${ }^{43}$ According to Heintz and Posel (2008: 2008), a comparison of Statistics South Africa and International Labour Organisation data for 2006 confirm that the ratios between non-agricultural employment in the informal sector and total employment were markedly higher in Latin and Northern American middleincome countries such as Argentina (36.1 percent), Brazil (40.6 percent), Mexico (38.0 percent) and Paraguay (50.1 percent) than in South Africa (18.5 percent). Data on the sizes of informal sectors in subSaharan African and Asian developing countries also suggest that the informal sector in South Africa is unusually small (cf. Kingdon and Knight, 2004: 391-392).
} 
Two explanations come to mind for the reality that the informal sector in South Africa is much smaller than what one would expect in view of the extent of unemployment ( $c f$. Kingdon and Knight, 2004: 393). The supply-side explanation is that a large portion of the unemployed may prefer not to join the informal sector, either because they have access to alternative forms of income which enable them to exercise a preference for leisure over work or because informal-sector participation hampers searching for preferred formal-sector jobs. The implication of this explanation is that a considerable portion of South Africa's unemployment is voluntary. The demand-side explanation hinges on the existence of barriers of entry which prevent unemployed workers from joining the informal sector, in which case unemployment would be involuntary.

In a careful study of the evidence, Kingdon and Knight (2004) found no conclusive evidence of widespread involuntary unemployment in South Africa ( $c$. also Heintz and Posel, 2008). The "luxury unemployment" interpretation of joblessness is unrealistic: survey evidence has consistently found that informal-sector workers are markedly better off in terms of income and expenditure than the unemployed, and members of the former group tended to be markedly more satisfied with their living standards than members of the latter (Kingdon and Knight, 2004: 395-401). Hence, it seems most unlikely that social grants or any other form of non-wage income makes it unnecessary for the unemployed to join the informal sector. Kingdon and Knight (2004: 403-404) interpreted this as evidence of the existence of significant barriers to entry into the informal sector, including factors such as the impact of apartheid education and restrictions on the development of entrepreneurial skills among blacks, crime and insecurity, inadequate government support, and the lack of credit for start-up capital.

Future trends in economic growth and job creation will be major determinants of the numbers of people who will need government assistance in the form of social grants or other interventions. Table 9 provides rough estimates of the extent of job creation and changes in unemployment numbers and rates that could result from constant economic growth rates of 3 percent and 6 percent between 2009 and 2019, given certain assumptions regarding labour-force growth and the employment intensity of growth. ${ }^{44}$

Crude as they are, these projections illustrate important aspects of the links among economic growth, job creation and unemployment in South Africa. The estimated effects of an economic growth rate of 3 percent per annum indicate that even comparatively modest rates of economic growth should contribute to job creation and reductions in the unemployment rate, but not necessarily the absolute number of unemployed. Such growth rates clearly will not materially reduce the number of poor people dependent on anti-poverty interventions (including social grants targeted at economically inactive vulnerable groups). Both the Gear and Asgisa strategies were aimed at achieving economic growth rates of 6 percent per annum. The projected effects suggest that such growth rates should result in large-scale job creation and marked reductions in the unemployment rate and the number of unemployed. Yet the extent of joblessness in South Africa is such that even a decade of rapid growth and job creation could leave almost 10 percent of the labour force (roughly 1.9 million work seekers) unemployed.

\footnotetext{
${ }^{44}$ These assumptions are as follows: (i) the employment intensity of economic growth will remain at its long-run average of 0.5 ; (ii) the working-age population will grow at a rate of 1.2 percent per annum (as in 2009), and (iii) the labour-force participation rate will remain constant at its 2009 level of 55 percent. Hence, the exercise ignores the possibility of changes in the number of discouraged work seekers.
} 
Table 9

Projections of job creation and unemployment (2009-2019)

\begin{tabular}{|lrrr|}
\hline & 2009 & 2019 & Change \\
\hline Working-age population ('000) & 31261 & 35184 & 3923 \\
Labour force ('000) & 17138 & 19351 & 2213 \\
& Economic growth of 3 percent per annum: & \\
Employment ('000) & 12974 & 15057 & 2083 \\
Unemployment ('000) & 4164 & 4294 & 130 \\
Unemployment rate (\%) & 24.3 & 22.2 & -2.1 \\
& Economic growth of 6 percent growth per annum: & \\
Employment ('000) & 12974 & 17436 & 462 \\
Unemployment ('000) & 4164 & 1915 & -2249 \\
Unemployment rate (\%) & 24.3 & 9.9 & -14.4 \\
\hline
\end{tabular}

Source of 2009 data: Statistics South Africa (2009a)

\subsection{The future role of social grants in South African anti-poverty policy}

A brief discussion of the determinants of poverty and of categories of interventions to address them is a useful starting point for discussing the possible future role of social grants as an element of anti-poverty policy in South Africa. Devereux (2002a: 658-660) identified three causes of poverty, each of which requires particular interventions:

- $\quad$ Chronic poverty often results from low productivity, that is, an inability to generate adequate returns from labour and other productive inputs. Low productivity often is related to unemployment or underemployment, especially in developing countries. The aim of interventions to address such poverty should be to facilitate income generation by raising productivity.

- $\quad$ Transitory poverty usually is related to vulnerability to temporary falls in returns to labour or temporary increases in irreducible expenses. Two factors determine the extent of vulnerability of a household: the likelihood that it will be affected by a particular shock ("exposure") and its ability to cope with the shock and its effects ("susceptibility"). Depending on the causes of vulnerability, appropriate interventions could include direct cash transfers, microfinance programmes aimed at smoothing consumption, and measures to restore productivity.

- $\quad$ Another major cause of poverty is dependency, which comes about because personal characteristics (such as disabilities, old age or childhood) prevent some persons from earning an independent living. Direct cash transfers are the best interventions to address dependency-related poverty.

As was indicated in section 2.1 of this paper, the South African social assistance system was designed to mitigate dependency-related poverty: grants are provided to needy members of vulnerable groups who are not members of the labour force (the disabled and poor children and elderly individuals). Section 3 showed that the grants system is 
effective at addressing this particular manifestation of poverty. The various social grants are well targeted and have a significant mitigating impact on poverty. Uncertainty remains about aspects of the utilisation and incentive effects of the grants, but systematic evidence of widespread squandering of grant income and severe undesirable behavioural effects are yet to come to light. Furthermore, the child support grant and the old-age pension are used widely to enhance the nutrition and schooling of children, which represents investments in the human capital and productivity of future workers.

Although direct social assistance in the form of non-contributory grants is not available to the unemployed, the existing grants do impact on chronic poverty resulting from low productivity. This happens when grants (especially old-age pensions) are used to sustain unemployed labour-force members in multi-generational households. Section 3.2.3 showed that such sharing of grant income acts as a safety net and sometimes facilitates labour-market participation, but also ties some of the unemployed to rural areas where jobs are scarce. Furthermore, it carries the risk of diluting grant money to such an extent that all members of households supporting unemployed persons (including the targeted beneficiaries) could be dragged into poverty.

The case for maintaining the existing targeted social grants is very strong. These grants effectively assist poverty groups who otherwise would be extremely vulnerable in an environment where large-scale structural unemployment and the HIV/Aids pandemic put considerable pressure on informal social security systems. South Africa recently followed a growing number of countries by adding conditions to a social grants programme targeted at needy children. The purpose of conditional cash transfer schemes is to strengthen the developmental impact of social assistance systems. Section 4.4 discusses the merits of such interventions from a South African perspective.

The most vexing questions regarding the future of the South African social assistance system stem from the reality that it was not designed to mitigate chronic poverty resulting from structural unemployment. 45 The absence of dedicated assistance to the long-term unemployed has restricted the ability of the social grants system to reduce poverty in two ways: first, by excluding large numbers of poor households from coverage and; second, by giving rise to grant sharing that dilutes the benefits of those who are covered. As was indicated in section 3.1, the Government wisely has rejected calls to address this gap in the social assistance system by means of the adoption of a universal income grant. The introduction of such an expensive programme clearly will be out of the question in the next few years in view of the need for fiscal consolidation, and it is unlikely to be sustainable in macroeconomic terms thereafter as well ( $c f$. Thurlow, 2002; Van der Berg, 2002). The numbers may be different eight years down the line, but Van der Berg's (2002: 7) comment on the effectiveness of a basic income grant as an anti-poverty instrument remains valid:

\footnotetext{
45 The social assistance system came into being in the interwar period to meet the needs of whites. At the time, job reservation and higher education and skill levels assured most whites of employment, and they mainly needed cover against cyclical unemployment, which was usually mild and of relatively short duration. The cover provided by the Unemployment Insurance Fund was adequate for this purpose, and there was no need for social grants to address structural unemployment.
} 
The BIG uses a sledgehammer where this is clearly an inappropriate instrument. To transfer perhaps another R22 billion to the poorest forty percent of the population (already an overly ambitious goal that would stretch fiscal resources), it proposes that another R32 billion be paid to the not so poor, some of whom would then have to pay taxes of R65 billion to fund all of this (including the costs of transfers).

A basic income grant also is likely to be a disincentive to labour-market participation and could contribute to unhealthy welfare dependency among the poor. Moreover, the introduction of such a large entitlement programme represents a form of "open-ended fiscal exposure" which may expose future governments to strong pressure for increases in the amount of the grants (cf. Coleman, 2002: 22).

Two interventions currently provide assistance to the unemployed: the Unemployment Insurance Fund (UIF) and the Expanded Public Works Programme (EPWP). The impacts of these interventions are considerable, but inadequate. As was indicated in section 2.1.2, the National Treasury (2010a: 107) reported that the UIF disbursed about R495.8 million per month to an average of 207967 beneficiaries during the first nine months of 2009/10. Hence, the Fund assisted some 5 percent of the more than 4.1 million unemployed members of the labour force (this ratio falls to about 4 percent if the more than 1 million discouraged work seekers are also taken into consideration). One of the main reasons why this ratio is so low is that most of the unemployed have never worked and therefore do not qualify for UIF assistance. ${ }^{46}$ Executives of the UIF recently informed the Parliamentary Portfolio Committee on Labour that the Fund is giving consideration to raising the income replacement rate and extending the period during which benefits are provided from 238 days to 365 (Ensor, 2010).

The target of the first phase of the EPWP, which ran from 2004 until 2009, was the creation of 1 million short-term work opportunities (i.e. 650000 full-time equivalent jobs). ${ }^{47}$ Table 10 shows that the EPWP achieved this target by creating 1709675 work opportunities in net terms. The Programme clearly had a significant impact: apart from providing work opportunities equivalent to full-time employment for roughly 10 to 15 percent of the unemployed, it supplied more than 7.1 million person-days of training, and wage payments to workers amounted to at least R6 725.9 million at an average minimum daily rate of R53 (Department of Public Works, 2009: 110). ${ }^{48}$

EPWP wage disbursements nonetheless were relatively small compared to total outlays on the Programme (R49 687 million) and the total spending on social grants over the same period (R285 807 million). ${ }^{49}$ Phase II of the EPWP, which commenced in 2009,

\footnotetext{
${ }^{46}$ The Labour Force Survey of September 2007 indicated that 55 percent of the unemployed have never worked (Leibbrandt et al., 2010: 48).

${ }^{47}$ A full-time job opportunity is defined as one that provides a minimum of 230 hours of work per year (Altman and Hemson, 2007: 10).

${ }^{48}$ The wage bill to employees was calculated as the product of the number of person-days of work and the average daily minimum wage (cf. footnote 4 to table 11). As such, it represents a lower-bound estimate of total wage payments. Official EPWP documentation does not provide more exact wage bill data.

${ }^{49} \mathrm{High}$ non-wage costs often reduce the poverty impact of public works programmes (Vodopivec, 2006: 66-67). To be sure, the purpose of most such programmes extends beyond supplying workers with cash wages: training and the creation and maintenance of infrastructure usually are important goals as well. This is the basis of the distinction between two types of public works programmes, namely labour-
} 
represents a major expansion of the Programme and also aims to address some of the weaknesses of the first phase by increasing the lengths of work opportunities and the labour intensity of projects (National Treasury, 2010a: 50). Total spending is expected to amount to R52 billion over the next three years, and the aim is to create 4.5 million short-term jobs lasting 100 days on average (National Treasury, 2010a: 51). According to the Department of Public Works (2009: 142), this target is the equivalent of slightly more than 2 million full-time jobs, that is, some 650000 jobs per annum. The possible contribution of the second phase of the EPWP to the reduction of joblessness should be assessed against the scale of the unemployment problem in South Africa: as was shown in section 4.2, even exceptional economic performance over the next decade (a constant real output growth rate of 6 percent per annum) is likely to only reduce the number of unemployed from the current 4.1 million to about 1.9 million.

\section{Table 10}

Outcomes of Phase 1 of the Expanded Public Works Programme (2004-2009)

\begin{tabular}{|lrrrr|}
\hline Year & $\begin{array}{r}\text { Expenditure } \\
\left(\mathrm{R}^{\prime} 000000\right)^{1}\end{array}$ & $\begin{array}{r}\text { Net work } \\
\text { opportunities }^{2}\end{array}$ & $\begin{array}{r}\text { Average daily } \\
\text { minimum wage } \\
(\mathrm{R})^{3}\end{array}$ & $\begin{array}{r}\text { Wages paid to } \\
\text { Employees } \\
\text { (R'000 000) }^{4}\end{array}$ \\
\hline $2004 / 2005$ & 3158 & 174845 & 50 & 823.2 \\
$2005 / 2006$ & 2482 & 208898 & 48 & 635.7 \\
$2006 / 2007$ & 7204 & 316814 & 41 & 917.5 \\
$2007 / 2008$ & 13640 & 439099 & 44 & 1720.6 \\
$2008 / 2009$ & 23203 & 570019 & 64 & 2628.9 \\
\hline Total & 49687 & 1709675 & 53 & 6725.9 \\
\hline
\end{tabular}

Source: Department of Public Works (2009: 150, 158, 170, 182, 194)

Notes: 1 Including professional fees

2 Gross work opportunities minus possible work opportunities if the projects had been undertaken machine-intensively (i.e. opportunities added by the EPWP).

3 For manual workers

4 Product of the minimum wage and the number of person-days of work

The South African Government recently announced another intervention aimed at job creation, namely a wage subsidy scheme. The purpose of this scheme (which is expected to be in operation early in 2011) will be to encourage firms to hire young work seekers without work experience (Gordhan, 2010: 10). It is envisaged that the scheme will use the SARS payroll tax platform to provide a cash reimbursement to employers for a twoyear period. To qualify for the subsidy, participating businesses, municipalities and nongovernmental organisations will be expected to adhere to minimum labour standards. ${ }^{50}$

intensive employment programmes aimed at maximising short-term job creation and labour-based employment programmes, which give as least as much attention to objective of asset creation (cf. Devereux, 2002b: 2). It nonetheless remains true that social grants programmes normally achieve significantly higher cash transfer-to-total expenditure ratios than public works programmes.

50 The National Treasury undertook to release a discussion document on the envisaged wage subsidy scheme at the end of March 2010. 
The notion of a wage subsidy has been on the policy agenda in South Africa for some time, having been mooted in 2007 in the context of retirement provision reform as an intervention to encourage job creation and the payment of living wages in labourintensive sectors and low-wage occupations (National Treasury, 2007b: 112-113). It also was proposed by the Harvard University team that assisted the South African Government in the preparation of the Asgisa strategy (Levinsohn, 2008). The Minister of Finance indicated that the goal of the envisaged scheme would be to increase employment of young school-leavers by 500000 by 2013 (cf. Gordhan, 2010: 10). It is difficult to judge the feasibility of this target. Attempts to model the effects of hypothetical wage subsidy schemes for unskilled and semi-skilled workers (e.g. Pauw and Edwards, 2006; Go, Kearney, Korman, Robinson and Thierfelder, 2009) indicated that such interventions should stimulate employment in South Africa, but the strength of the impact will depend on the elasticities of substitution of production factors and the flexibility of the labour market. This suggests that the decision to launch such a scheme on a limited scale by targeted a specific cohort among the unemployed was sensible.

Of late, attention is also being given to the scope for using the existing grants to provide increased access to economic opportunities to able-bodied household members of grants recipients. This idea was the topic of a discussion document released by the Department of Social Development (2006) and also featured in the draft discussion document on an anti-poverty strategy for South Africa, which suggested that the administrative structures of the grants system could be a facilitating mechanism for anti-poverty interventions:

The channel of grants' administration offers a unique opportunity to reach poor working and unemployed people to enhance their participation in the economy. The objective is to identify scalable policy options that could be linked to the grants, insofar as they enhance the access to economic opportunity for labour market participants in beneficiary households... It will... allow for targeting interventions to have greater impact. (The Presidency, 2008: 50)

In a paper commissioned by the Department of Social Development, Altman and Boyce (2008) identified varied policy options of this nature. Such interventions are related to elements of the workfare programmes that have been adopted by the United States and a growing number of European countries. Section 4.5 comments on the scope for implementing such programmes in South Africa.

\subsection{Conditional cash transfers}

\subsubsection{Overview and international experience}

Rawlings (2005: 134) summarised the essence of conditional cash transfer (CCT) programmes as follows: "Conditional cash transfers provide money to poor families on condition that they make investments in human capital such as sending children to school or bringing them to health centres on a regular basis". The first CCT programme was the Progresa scheme introduced in Mexico in 1971. Progresa consisted of cash and in-kind transfers to households whose children regularly attended school and whose members all visited health centres regularly. The education component of Progresa targeted poor households with children in primary and secondary school, and provided 
educational grants and support for school materials. The programme also included supply-side benefits: teachers, for example, received bonuses for every pupil who was on the programme. The health component focused on poor households with pregnant and lactating women, children under two years of age, and malnourished children between the ages of two and five; the benefits included cash grants for food consumption, basic health care services, nutrition and health education, and nutrition supplements (Rawlings and Rubio, 2005: 32). Furthermore, Progresa had a positive gender bias: benefits were disbursed to the female heads of participating households, and participating secondary-school girls received higher cash grants than boys, because the former face higher risks of dropping out of school and their educational attainment brings positive externalities (Britto, 2005: 8). In 2002, Progresa was renamed Oportunidades and its scope was expanded to also include income generation for poor households by means of preferential access to microcredit, housing improvements, and adult education (Rawlings and Rubio, 2005: 32).

Subsequently, several other Western Hemisphere developing countries also adopted CCT schemes, including Brazil, Colombia, Honduras, Jamaica and Nicaragua. Brazil, for example, adopted the Bolsa Escola scheme in 2001. This programme granted monthly cash transfers to poor households with children aged six to fifteen enrolled in grades one to eight, provided that they maintained school attendance rates of 85 percent or higher (Britto, 2005: 10-11). Bolsa Escola benefits were also disbursed to female heads of households. The benefits provided by Brazil's federal government were significantly lower than those of Progresa, but richer states and municipalities were allowed to raise the transfers or expand coverage. The details of the targeting of beneficiaries were also left to municipalities (Britto, 2005: 11). In 2003, Bolsa Escola was unified with other federal CCT schemes, creating a programme known as Bolsa Família. Apart from better coordination with other social spending initiatives, Bolsa Família added health-related conditionalities to Bolsa Escola's education-related ones and markedly extended the coverage and size of transfers.

The adoption of CCT schemes was a direct response to the shortcomings of traditional social assistance programmes, including high administrative costs, poor targeting of the needy, fragmentation of projects and programmes, and an overemphasis on short-term relief of poverty with inadequate attention to longer-term poverty of a structural nature (Rawlings and Rubio, 2005: 30,33). Hence, the explicit aim of CCT schemes is to combat current poverty (by providing income support that enables consumption smoothing) as well as future poverty (by encouraging human capital accumulation among the young in an attempt to break the intergenerational poverty cycle) (Das, Do and Özler, 2005: 57; Rawlings and Rubio, 2005: 33). Other notable features of Latin American CCT schemes have included strong emphasis on obtaining co-responsibility for the success of interventions from participants; an explicit focus on achieving complementarities between the education, health and nutrition elements of human capital development; carefully planned impact assessment (which also were used as bases for expanding programmes); and various innovative targeting mechanisms (Rawlings, 2005: 144-148; Rawlings and Rubio, 2005: 36-38). ${ }^{51}$

51 CCT programmes use a variety of targeting mechanisms (mainly a combination of geographical and household-level targeting, sometimes based on proxy means tests) (cf. Rawlings, 2005: 145; Rawlings and Rubio, 2005: 36-38). Honduras uses the Height Census of First Grade School children to provide data on malnutrition levels. In Mexico, qualifying communities in rural areas are selected using a marginality 
According to Das et al. (2005: 57), CCT programmes "... are technically feasible in that the main stated goals of the programs are actually met in practice and are politically acceptable in that successive governments are willing to continue and even expand program coverage". The political acceptability of CCT programmes was reflected in marked increases in budgets and the number of recipients over time. When Progresa began in Mexico it involved 300000 individuals; by 2002, the number of participants had grown to more than 4 million (20 percent of the population) (Rawlings and Rubio, 2005: 38). The same trend was observed in Brazil, where some 5 million people participated in Bolsa Escola in 2002 (Britto, 2005: 7). Rawlings (2005: 149-151) summarised evidence on the effectiveness of CCT schemes as follows:

- $\quad$ Primary and secondary school enrolment rates have increased markedly in Mexico, Colombia and Nicaragua since the introduction of CCT schemes.

- $\quad$ The impact of CCT programmes on school attendance has been mixed, ranging from very impressive in Nicaragua to modest in Mexico.

- It appears as if the introduction of CCT programmes has significantly reduced the incidence of child labour in Mexico and Brazil.

- In several countries (including Mexico, Colombia and Nicaragua), child health and nutrition have also improved since the adoption of CCT programmes.

- Participation in CCT programmes apparently has contributed to higher consumption levels in Mexico, Colombia and Nicaragua.

- Evaluations have suggested that CCT programmes are efficient (81 percent of the programme benefits have accrued to the poorest 40 percent of families) and cost-effective in terms of the ratio between benefits and administrative costs.

These findings are encouraging, but it should be kept in mind that it is still too soon to properly gauge the longer-term developmental impact of conditional cash transfer programmes (Rawlings, 2005: 154). More generally, such interventions by no means are panaceas for solving the challenge of designing effective social assistance systems. CCT programmes can be effective for overcoming obstacles to full use of schools and health clinics by the poor, including high pecuniary and opportunity costs, difficult access and inadequate incentives for investing in the human capital of children (Rawlings and Rubio, 2005: 33). Clearly, such schemes cannot address the short-term consumption needs of poor households without young children. Furthermore, their impact on human capital accumulation will be negligible in areas where school enrolment and attendance among poor children are high already or where service delivery institutions are absent or incapable of providing high-quality education and health services (Rawlings, 2005: 156; Rawlings and Rubio, 2005: 33). In such cases, the introduction of CCT programmes should be complemented by increased investment in and institutional reform of the supply of education and health care.

index based on census data. Furthermore, in Jamaica, beneficiaries' eligibility is continuously reviewed. This happens every three years in Mexico as well. In Nicaragua the programme only lasts three years in a community and is then phased out within two years. 


\subsubsection{Application to South Africa}

In some ways, conditional cash transfer programmes are attractive interventions in the current South African context: in return for what should be a modest increase in administrative costs associated with monitoring compliance, such schemes promise significantly higher returns on current social grants spending (mainly accelerated human capital accumulation among children in poor households). Moreover, the adoption of CCT programmes would not require modification of a design principle that is deeply entrenched in South Africa, namely that social assistance should be limited to economically inactive vulnerable groups.

The National Treasury (2008b: 94) first indicated an interest in adding conditions to the child support grant in February 2008, when it announced that "a review will be undertaken this year of the grant's administration and targeting mechanisms, and of appropriate conditional criteria, such as school attendance and immunisation of qualifying children". The 2009 Budget Review (National Treasury, 2009a: 91) confirmed that "... research has been undertaken on options for linking grants to key aspects of child care, such as schooling and health monitoring", but failed to report any concrete findings. Conditions for the child support grant were introduced effective from 1 January 2010 ( $c f$. National Treasury, 2010a: 104). This entails that the caregivers of beneficiaries must (1) ensure that they are enrolled and attending school, and (2) submit regular proof of enrolment and reports from the school to the Department of Social Development. In cases where these conditions are breached, the Department of Social Development will send a social worker to investigate and institute steps to ensure that the child attends school. However, punitive measures (such as terminating the grant) are not envisaged.

Das et al. (2005) suggested a useful conceptual framework for assessing the need for and likely effectiveness of conditional cash transfers in a variety of settings. Their point of departure was a standard theoretical argument for the superiority of unconditional cash transfers over conditional cash transfers: all other things equal, successful attempts to change the behaviour of rational (non-myopic) poor agents by means of conditional transfers reduce their welfare, because such efforts distort the decisions of the agents by inducing them to make choices which they would not have made otherwise (Das et al., 2005: 63). They then posed the following question: could there be market failures which prevent poor agents from making optimal choices, in which case appropriately designed conditional cash transfer programmes could enhance efficiency and the welfare of individual agents and society as a whole? Das et al. (2005: 64-71) identified the following possible market failures which could make conditional cash transfer interventions welfare-enhancing:

- $\quad$ Efficiency-related market failures. Mismatches between the interests of children and the preferences of parents could result in underinvestment in the education of the former. Children cannot credibly commit themselves to repaying parents for investments in their schooling. Hence, some parents may prefer inferior short-run outcomes which benefit them relatively more (e.g. higher incomes resulting from child labour or from using school-age children to look after younger siblings) to superior long-run outcomes involving relatively larger gains for the children. In such cases, cash grants tied to school enrolment and 
attendance could yield higher levels of efficiency and welfare by reducing or eliminating the gap between parental preferences and children's interests.

- $\quad$ Equity-related market failures. When it is not feasible to use conventional means testing for targeting purposes, attaching conditions to a cash transfer scheme programme can be a useful self-targeting alternative. The idea would be to use conditions which would tilt the cost-benefit calculation of higher-income groups against participation in the scheme (e.g. prescribing periodic visits to public health facilities which require a degree of queuing that would impose high opportunity costs on richer people with access to other health facilities).

Yet the existence of such market failure is not a sufficient rationale for the adoption of CCT programmes. Das et al. (2005: 66-69) note that conditions may not have the desired effects if the perception that the costs of the condition(s) outweigh the benefits of the grants causes potential participants to shun the programme. Another possible cause of programme failure is the fungibility of most conditioned-on commodities: participants could undermine CCT programmes by switching their consumption to close substitutes of the conditioned-on goods (e.g. by decreasing their consumption of oranges when given vitamin $\mathrm{C}$ tablets, or by reducing the food intake of children at home when they participate in school lunch programmes). Thus, careful cost-benefit analysis is required to estimate the potential effectiveness of CCT programmes.

On balance, lessons from the experiences of other countries and the issues raised by Das et al. (2005) suggest that conditional cash transfer programmes are unlikely to be costeffective interventions in the current South African context. CCT programmes work on the demand side of social-service provision, but this is not where the real problems are to be found in South Africa as far as these services are concerned. ${ }^{52}$ School enrolment and attendance figures, for instance, are high already: General Household Survey data showed that the school attendance ratio among 5 to 19 -year olds in grant-receiving households was 90 percent in 2007, up from 87 percent in 2003. For 5 to 19-year olds in living in low-earning households receiving child support grants, the school attendance ratio increased from 86 percent in 2003 to 90 percent in 2007 (Statistics South Africa, 2009b: 17-18). Furthermore, the success of existing targeting mechanisms precludes the need to use conditions for screening purposes. Inefficiency and effectiveness on the supply side of the social service provision are major obstacles to human capital accumulation among poor children in South Africa ${ }^{53}$; indeed, in some cases, supply-side problems are already weakening the demand for publicly provided social services for which private alternatives exist. ${ }^{54}$ Unless these problems are

\footnotetext{
52 The introduction of no-fee schools, for example, has markedly reduced the pecuniary costs of education to poor parents in South Africa.

53 This issue also was highlighted by another assessment of the potential of CCT programs in the South African context (Lund, Noble, Barnes and Wright, 2008: 16): "... school attendance rates are good (though they may become less so with HIV/AIDS). Given the parlous quality of education for poor South Africans in both urban and rural areas, it is not necessarily getting children to school that matters in breaking long term poverty: it is about resources and facilities, or management, or teaching practice at schools... It is a supply-side problem... Poor teaching and lack of leadership in under-resourced schools are common, and there are low returns to education for a number of years. Enrolment and attendance are necessary conditions in trying to escape poverty, but they are not sufficient."

${ }^{54}$ An example of this is health care, where even lower-income groups show an overwhelming preference for private care, where it is available and affordable ( $c f$. Van der Berg et al., 2009: 36).
} 
addressed, the most likely effect of the adoption of conditions is likely to be a dilution of the current poverty impact of the child support grant resulting from higher administrative and compliance costs. This would be most unfortunate given the need for effective anti-poverty interventions and the situation of severe fiscal stress in South Africa right now.

The conditions introduced for the child support grant with effect from 1 January 2010 therefore make little sense. The constraint on human capital accumulation by means of the schooling system is the supply-side problem of ineffectiveness in provision, not demand-side problems related to low enrolment or attendance; furthermore, the intervention lacks credible sanctions for non-compliance on the part of participants. One reason for the absence of sanctions could be that making eligibility for the child support grant conditional upon school attendance sits uneasily with the rights-based approach of the South African Constitution. Section 27(1)(c) of the Constitution of the Republic of South Africa (No. 108 of 1996) stipulates that everyone has the right to have access to social security, including appropriate social assistance for those unable to support themselves. Be that as it may, whatever human capital investment may result from the adoption of the conditions probably will not outweigh the accompanying increase in the administrative and compliance costs of the child support grant scheme.

\subsection{Workfare programmes}

\subsubsection{Nature and international experience}

Standing (1990: 680) defined workfare as a "government-administered policy whereby those in need and without regular employment are obliged to undertake work-related activity in return for state income transfers". A further distinction is sometimes made between two categories of workfare schemes which impose different types of obligations on the recipients of social grants: mandatory workfare requires actual work, while "new-style" workfare requires participation in other employment-related programmes (such as job-seeking, community work, training and formal schooling) (Standing, 1990: 680). ${ }^{55}$ Public works programmes (such as the EPWP) therefore are examples of mandatory workfare schemes. This section focuses on "new-style" workfare programmes.

Contemporary workfare programmes originated in OECD countries, where trends such as rising long-term unemployment and changing family structures prompted concern about the work incentive effects of traditional social assistance systems and their ability to address growing social exclusion (Tesliuc, 2006: 5-8). Core elements of such programmes have included steps to reduce the amounts and duration of benefits and to force beneficiaries to seek work actively, often complemented by other measures to encourage working and social inclusion, including termination of the cancelling of benefits when recipients obtain part-time work, changing the delivery of benefits from the household to individuals so that individuals do not jeopardise the household's access to benefits when they find jobs, making the provision of benefits conditional on finding employment (e.g. cash bonuses, wage supplements and tax credits), and offering more assistance to job seekers (labour-market information, training programmes, etc)

\footnotetext{
55 Hence, workfare programmes are a subset of conditional cash transfer programmes, but with a specific focus on members of the labour force.
} 
(Tesliuc, 2006: 7). ${ }^{56}$ Hudson and Kühner (2009) described this development as a shift from "protective" to "productive" modes of providing social assistance. ${ }^{57}$

The United States pioneered modern welfare reforms aimed at integrating recipients of social benefits into the formal labour market. The workfare approach can be traced back to experimental programmes introduced by the Reagan Administration in 1981, but reached maturity under the Clinton Administration with the implementation of the Personal Responsibility and Work Opportunity Act (PRWORA) of 1996 and other welfare reforms. The major elements of US workfare programmes have been as follows (cf. Blank, 2004: 4-8). First, PRWORA abolished the matching-grant Aid to Families with Dependent Children (AFDC) programme and replaced it with Temporary Assistance to Needy Families (TANF), provided to states as a block grant. The introduction of TANF allowed the states much more discretion over programme design than AFDC, and the block-grant basis raised the importance of careful design by transferring the full financial risk of cycles in assistance needs to states. The PRWORA legislation also made access to federal funds conditional on states placing larger numbers of their active welfare recipients in jobs, limited TANF-funded assistance to 60 months over the full lifetimes of individuals, and limited access to income assistance programmes by certain targeted groups (e.g. immigrants and certain categories of disabled persons). The states responded to the PRWORA legislation by:

- $\quad$ markedly expanding their welfare-to-work programmes

- $\quad$ reducing the rate at which cash benefits decrease as earnings increase (to encourage working)

- enforcing sanctions (benefit losses) on assistance recipients who did not participate in work programmes

- $\quad$ enforcing the Federal 60-month limit on eligibility for TANF-funded assistance and, in some cases, setting and implementing even tighter limits

Other policy changes strengthened state-level efforts to get welfare recipients in jobs. These included the expansion of in-kind assistance to needy families by means of childcare subsidies, food stamps and Medicaid services, as well minimum wage increases and expanded refundable tax credits under the Earned Income Tax Credit (EITC) system (Blank, 2004: 9-12).

In a careful review of the empirical evidence, Blank (2004: 14-18) highlighted three major results of these changes:

- $\quad$ The number of persons on the welfare rolls dropped by 42 percent from 1994 to 2001 , and did not rebound significantly during the 2000-2001 recession.

- $\quad$ Employment increased sharply during the late-1990s, especially among lessskilled single mothers. Data from 2002 showed that the majority of the women

\footnotetext{
56 Ochel (2005: 78) emphasized that workfare programmes focus primarily on work; training and other mechanisms to achieve reintegration into the labour market are of secondary importance.

57 This shift also could be described in terms of the typology proposed by Devereux (2002a: 661, 662) as one from a "livelihood protection" to a "livelihood promotion" approach (cf. section 3.2.2).
} 
who had left welfare in the 1990s remained employed, although a significant minority were jobless.

- $\quad$ The incomes of single mothers (the group affected most heavily by the changes) rose during the second half of the 1990s, despite the fact that many of them lost cash benefits as a result of the introduction of workfare.

These developments suggest that workfare programmes have succeeded in their primary aims of reducing welfare caseloads and moving welfare recipients into jobs. Blank (2004: 37-40), however, added that it is particularly difficult to separate the effects of such programmes from concurrent labour-market developments such as the rapid growth in job opportunities and earnings in the US during the second half of the 1990s; furthermore, it is too soon to ascertain some of the longer-term effects of the welfare reforms on the livelihoods and social choices of needy families.

Welfare reforms with workfare elements were also implemented in the United Kingdom by the Labour Government of Tony Blair, as well as in the Scandinavian countries. The UK reforms, known as the New Deal, offer assistance to four groups of welfare recipients: young unemployed persons aged 18 to 24, long-term unemployed aged 25 and above, lone parents and disabled people (cf. Kildal, 2001: 4; Ochel, 2006: 80-81). Younger unemployed persons first entered a period of intensive job-search (the "Gateway"), after which they had to choose among four six-month options, namely subsidised employment, full-time education and training, voluntary service, and the Environmental Task Force (Ochel, 2006: 80). This was followed by another period of intensive job search (known as the "follow-through"). Unemployed persons aged 25 and above who had received the Jobseeker's Allowance continuously for 12 to 18 months underwent a 13-week Gateway period, followed by an Intensive Activity Period that lasted another 13 weeks and provided subsidised employment or education and training opportunities (Ochel, 2006: 81). Several studies reviewed by Ochel (2006: 8081) found that the New Deal programmes successfully promoted the employment of younger and long-term unemployed people in the United Kingdom.

The Scandinavian countries have long combined a commitment to the maintenance of full employment (pursued by means of active labour-market policies, inter alia) with the belief that generous social benefits for the unemployed are basic social rights regardless of achievements and financial means ( $c f$. Kildal, 2001: 5-6). During the second half of the 1990s, however, the governments of these countries also introduced workfare-like welfare reforms, with Denmark leading the way. Prior to a series of labour-market reforms introduced from 1993 until 1998, the jobless in Denmark could have accessed unemployment benefits indefinitely, provided that they had participated in work programmes for six months during each three-year benefit cycle (Kildal, 2001: 7-9). The first wave of reforms abolished the right to earn new benefits through participating in work programmes by limiting the period of entitlement to seven years, of which the last three years involved compulsory "activation initiatives" aimed at reintegration into the labour market. The limits subsequently were tightened and by 1998 the maximum unemployment period was four years, including three years of activation activities. In 1996, these steps were complemented by special measures for low-skilled individuals under 25 years of age, who after six months of unemployment were compelled to enter education or work-training programmes and accept sharply reduced benefits. Ochel (2006: 81) reported positive employment effects for these Danish workfare 
programmes, but Kildal (2001) was more circumspect and expressed concern about the implications of such programmes for norms of fairness and justice that have long underpinned the Scandinavian welfare regimes.

The available evidence therefore indicates that workfare programmes can be effective mechanisms for returning welfare recipients to work, especially in rapidly growing economies where sufficient numbers of jobs are created to absorb programme participants in the regular labour market. The importance of the availability of jobs is magnified by the reality that workfare programmes affect the low-skilled labour market by assisting unemployed people in getting regular public or private sector employment. In contrast to public works programmes, which provide government-created temporary jobs, workfare therefore causes competition between social security recipients and regular workers for low skilled work in the formal labour market (e.g. sweeping streets, cleaning parks, and basic clerical tasks). Hence, inadequate availability of jobs may well be the most serious barrier to the successful implementation of workfare programmes. Moreover, the US experience showed that workfare programmes can be timeconsuming and financially expensive: the costs to be taken into consideration are the work-related and child care expenses of recipients as well as supervisory and administrative costs (Samson, Rosenblum, Haarmann, Haarmann, MacQuene and Van Niekerk, et al., 2001: 12). Kildal (2001: 14) also warned that workfare-type schemes could easily lead to two-tiered labour markets in which poor labourers are compelled to work on "second-rate terms", lacking labour rights and sickness, vacation and unemployment benefits.

\subsubsection{Application to South Africa}

The discussion document released by the Department of Social Development (2006: 7) acknowledged that efforts relying solely on conditions-based incentives are unlikely to successfully draw the poor and beneficiaries of social grants into economic activity in South Africa. Hence, it argued for a more holistic approach that provides for a range of supporting measures to enable these groups to access economic opportunities. To this end, the document proposed the interventions listed in table 11 to assist the various age cohorts. Specific attention was given to two sets of interventions: "exit strategies" for the beneficiaries of child support grants and persons with disabilities capable of rehabilitation, and measures to assist the care givers of beneficiaries of child support grants. ${ }^{58}$ The document also outlined the rudiments of a process model for such interventions. According to the envisaged model, one agency would be responsible for compiling a so-called "gateway profile" for targeted beneficiaries, assisting them in exploring options, providing them with income incentives, and entering into a "social contract" with them. This agency also would be charged with referring beneficiaries to partner institutions providing the actual economic opportunities, for example the Department of Labour, the Department of Education and civil society organisations (Department of Social Development, 2006: 8).

\footnotetext{
58 The rationales for these foci included that 36 percent of the beneficiaries of disability grant at the time had physical disabilities which did not preclude them from doing certain types of work, and that more than 85 percent of the care givers of child support grant beneficiaries were unemployed (Department of Social Development, 2006: 3,5).
} 
In a report commissioned by the Department of Social Development, Altman and Boyce (2008: 5) fleshed out these principles by identifying five policy instruments ("direct job placement and job creation, top-up subsidies or vouchers, credit for productive activities, information, and insurance") and four general policy options ("direct job creation, enhancement of job search and employability, support for self-employment, and support to stabilise income from employment or self-employment"). Application of these instruments to the various policy options yielded the following proposals for interventions (Altman and Boyce, 2008: 22-33):

- $\quad$ Direct job creation. Access to EPWP opportunities could be facilitated by means of dissemination of information, while vouchers could be used to stimulate activity in the social sector of the Programme (e.g. child-care services). In addition, an employment voucher could be provided to working-age youth in beneficiary households to finance temporary work experiences.

- $\quad$ Enhanced job search and employability. Proposals included dissemination of jobsearch information, provision of education and training vouchers to members of beneficiary households, provision of transport coupons or subsidies to members of beneficiary households who manage to find jobs, and incentives to temporarily disabled grants recipients to return to work.

- $\quad$ Support for self-employment. Vouchers for the purchasing of advice and inputs, insurance against theft and access to credit could be made available to persons linked to grants beneficiaries.

- $\quad$ Stabilising incomes. Insurance for productive assets could be offered to increase the viability of businesses, while women in grant-receiving households could be provided with HIV/Aids services to enable them to remain employed.

Table 11

Proposed interventions to facilitate access to economic opportunities

\begin{tabular}{|lr|}
\hline Age cohort & Interventions \\
\hline$<18$ years & Child support grants \\
Disabled persons & Re-assessment; training and skills development \\
Single parents & Specific assistance based on age, background and skills \\
$18-22$ years & Tertiary and technical education; training support \\
$23-40$ years & Adult basic education; training and skills development; \\
& job placement in local industries \\
$41-50$ years & Training; job placement and self-employment support \\
$51-60$ years & Job placement in services industry \\
60 years $>$ & Old-age pensions \\
\hline
\end{tabular}

Source: Adapted from Department of Social Development (2006: 11)

These ideas clearly have much in common with the "new-style" workfare programmes of some OECD countries. Nonetheless, if such programmes were to be introduced in South Africa at this juncture, the purpose and systemic implications would differ in 
important ways from those in the OECD countries. These countries introduced workfare schemes to curtail social assistance dependence and spending; in South Africa, the adoption of such programmes would represent an expansion of the social assistance system. The fiscal costs of such programmes would depend on their scope and design, but large-scale interventions would be out of the question in South Africa in the present fiscal climate. Being additions to the South African social assistance systems, however, workfare programmes would not leave any of the poor worse off, as the imposition of work requirements and term limits on eligibility for assistance sometimes did in the United States.

Workfare-type programmes could be useful elements of anti-poverty policy in South Africa, but their potential impact should not be exaggerated. The very high level of unemployment and relatively low level of informal-sector participation highlighted in section 4.2 are indicative of a badly malfunctioning labour market. Workfare schemes and other job-creation initiatives could mitigate the symptoms of such malfunctioning, but lasting progress would require rectification of the causes of high unemployment in South Africa. These are likely to be found in the education system and in labour-market policy and practice. In the absence of job creation, the impact of workfare programmes could be restricted severely by the paucity of jobs available to participants.

While it makes no sense to adopt additional layers of policy measures to rectify distortions caused by existing interventions, workfare and other employment-creation initiatives can help to overcome market failures. Levinsohn's (2008: 9-11) proposal of a wage subsidy targeted at recent school leavers, for example, rested on the argument that market imperfections may well prejudice the employment prospects of younger work seekers in South Africa. Similar arguments could be made in support of some of the proposals of Altman and Boyce (2008), including dissemination of information about job opportunities, initiatives to improve access to credit among the poor, and provision of transport coupons or subsidies. In using market failures as criteria for judging the economic merits of workfare programmes, it should be kept in mind though that the prevalence of market failure is at best a necessary condition for government intervention: in practice, government intervention often gives rise to larger distortions than those caused by the market failures they were intended to address. The risk of government failure in the implementation of workfare programmes would be relatively high: the process model envisaged by the Department of Social Development (2006) would require coordinated decision-making by various institutions which also would have to deal with uncertainties regarding labour-market conditions and the ability and motivation of programme participants. ${ }^{59}$ Moreover, Altman and Boyce (2008: 24) made a very important point when they stated that "... simplicity in the aims and implementation has been an important strength of the social grants programme. Imposing requirements that may be difficult to monitor or even achieve could make the programme less successful".

\footnotetext{
59 The experience with the National Skills Development Strategy has underlined this danger. This Strategy has a clear and sound economic rationale, has had strong political support and has received ample funding. Yet according to the National Treasury (2010a: 50), implementation problems have severely blunted its impact: "... the system suffers from weak reporting requirements, underdeveloped capacity, lack of effective management, and inadequate monitoring and evaluation, limiting the ability of SETAs to serve as primary vehicles for skills development".
} 
International experience has highlighted the importance of political economy considerations in the design of workfare programmes. It is sometimes argued that work requirements make the extension of social assistance to employable persons more acceptable politically ( $c f$. Standing, 1990: 688). This claim, however, ignores the reality that workfare programmes often raise the ire of labour unions concerned about the possible development of a parallel labour market which might threaten worker rights and undermine the bargaining position of lower-skilled, lower-paid workers throughout the economy. Such opposition to workfare schemes from organised labour has come to the fore in the context of public works programmes in developing countries such as Argentina, Brazil and Chile (Seekings, 2006: 18-19). Moreover, left-wing critics of welfare reform in the United States have argued that workfare programmes exacerbate the downward pressure on the wages, job security and working conditions of ordinary workers caused by globalisation and firm-friendly economic policies (Midgley, 2008: 38-39). The Government obtained support for the Expanded Public Works Programme from organised labour by negotiating a Code of Practice for Special Public Works Programmes which governs wage-setting and other aspects of employment (Seekings, 2006:19), and something similar may be required depending on the nature of the economic opportunities provided as part of workfare programmes.

\section{$5 \quad$ POLICY IMPLICATIONS}

The South African social assistance system is an effective intervention which markedly reduces poverty and apparently does not have severe undesirable behavioural effects. The scope for strengthening anti-poverty policy in South Africa by further expanding the social grants system nonetheless has become very limited: attempts to do so could easily overburden the fiscus and encourage various types of undesirable behaviour. It would be particularly risky to introduce unemployment or universal income grants with a view to addressing the major lacuna in the social assistance system, namely the lack of support for unemployed members of the labour force without access to the Unemployment Insurance Fund and the Expanded Public Works Programme. The fact of the matter is that sustainable poverty reduction in South Africa requires inclusive jobcreating economic growth, and this should remain the primary focus of anti-poverty policy.

Several other policy implications follow from the contents of this paper.

\section{Short- to medium-term policy implications:}

- $\quad$ Social-assistance outlays should be protected as far as possible during the next few years. Fiscal consolidation, including strict public spending discipline, is now unavoidable in South Africa. The poverty-reducing effects of the social grants as well as their safety-net function (the importance of which was evident during the global economic crisis) strongly suggest that the scope and coverage of the grants system should not be diminished as part of the deficit-reduction process.

- $\quad$ Two options which could be considered if it does become necessary to restrain social assistance spending as part of the fiscal consolidation effort are, first, to temporarily reduce the real value of the grants (by keeping the annual increases in the grant amounts values below the inflation rate) and, second, to postpone the announced expansion of the child support grant to children up to the age of 
eighteen. These measures would reduce the pressure on social assistance spending while the budget deficit is being reduced without compromising the scope of the grants system.

\section{Longer-term policy implications:}

- Social assistance reform should not compromise the relative simplicity of the grants system. The relative simplicity of the social assistance system has been one of the cornerstones of its success, and care should be taken in designing future reforms not to compromise this characteristic by introducing complex institutional structures and conditions that are difficult to monitor or to achieve.

- $\quad$ The adoption of additional conditional cash transfer programmes targeted at needy children should be avoided. Such programmes make little sense in the present South African context: school attendance already is high and making eligibility for the child support grant conditional upon school attendance sits uneasily with the rights-based approach of the South African Constitution.

- $\quad$ Consideration should be given to adopting targeted workfare programmes aimed at expanding the range of economic opportunities available to the poor. Such programmes, however, could be costly and pose formidable design and implementation challenges. Moreover, their effectiveness is likely to be limited by the relatively slow pace of job creation in South Africa.

\section{REFERENCES}

Aguero, J.M., M. Carter and I. Woolard (2007): The impact of unconditional cash transfers on nutrition: the South African child support grant. IPC Working Paper No 39. Brasilia: International Poverty Centre.

Altman, M. and D. Hemson (2007): The role of Expanded Public Works Programmes in halving unemployment. Pretoria: Human Sciences Research Council.

Altman, M. and G. Boyce (2008): Policy options to leverage the system of social grants for improved access to economic opportunity. Paper prepared for the Department of Social Development. Pretoria: Human Sciences Research Council.

Armstrong, P., B. Lekezwa \& F.K. Siebrits (2008): Poverty in South Africa: a profile based on recent household surveys. Stellenbosch Economic Working Papers No 04/08. Stellenbosch: University of Stellenbosch (Department of Economics \& Bureau for Economic Research).

Armstrong, P. and C. Burger (2009): Poverty, inequality and the role of social grants: An analysis using decomposition techniques. Stellenbosch Economic Working Papers No 15/09. Stellenbosch: University of Stellenbosch (Department of Economics \& Bureau for Economic Research).

Arora, V. and L.A. Ricci (2005): Unemployment and the labor market. In M. Nowak and L.A. Ricci (Eds.): Post-apartheid South Africa: the first ten years. Washington, D.C.: The International Monetary Fund: 23-47.

Banerjee, A., S. Galiani, J. Levinsohn and I. Woolard (2006): Why has unemployment risen in the New South Africa? CID Working Paper No. 134. Cambridge, Mass.: Harvard University (Center for International Development). 
Banerjee, A., S. Galiani, J. Levinsohn, Z. McLaren and I. Woolard (2009): Why has unemployment risen in the New South Africa? Economics of Transition 16(4): 715-740.

Barrientos, A. (2003): What is the impact of non-contributory pensions on poverty? Estimates from Brazil and South Africa. Manchester: University of Manchester (Institute for Development Policy and Management).

Bertrand, M., D. Miller and S. Mullainathan (2003): Public policy and extended families: evidence from pensions in South Africa. World Bank Economic Review, 17(1): 2750 .

Bhorat, H. (2004): Labour market challenges in post-apartheid South Africa. South African Journal of Economics, 72(5): 940-977.

Blank, R. (2004): What did the 1990s welfare reform accomplish? Paper prepared for the Berkeley Symposium on Poverty and Demographics, the Distribution of Income, and Public Policy. Michigan, University of Michigan (Gerald R Ford School of Public Policy).

Britto, T. (2005): Recent trends in the development agenda of Latin America: an analysis of conditional cash transfers. Brasilia: Ministry of Social Development.

Budlender, D. and I. Woolard (2006): The impact of the South African child support and old age grants on children's schooling and work. TECL Paper No. 43. Geneva: International Labour Office.

Burger, R. and I. Woolard (2005): The state of the labour market in South Africa after the first decade of democracy. CSSR Working Paper No. 133. Cape Town: University of Cape Town (Centre for Social Science Research).

Burger, R. and D. Yu (2006): Wage trends in post-apartheid South Africa: constructing an earnings series from household survey data. Stellenbosch Economic Working Papers No 04/06. Stellenbosch: University of Stellenbosch (Department of Economics \& Bureau for Economic Research).

Calitz, E., S.A. du Plessis \& F.K. Siebrits (2009): Institutions and the sustainability of fiscal policy in South Africa, 1960-2008. Paper delivered at the Fifteenth World Economic History Congress in Utrecht (The Netherlands). 3-7 August 2009.

Coleman, N. (2003): Current debates around BIG: the political and socio-economic context. TIPS Forum Paper. Cape Town: University of Cape Town (Development Policy Research Unit).

Community Agency for Social Enquiry (CASE) (2008): Review of the child support grant: uses, implementation and obstacles. Report compiled for the Department of Social Development, the South African Social Security Agency (SASSA) and the United Nations Children's Fund (UNICEF). Johannesburg.

Case, A. and A. Deaton (1998): Large cash transfers to the elderly in South Africa. Economic Journal, 108: 1330-63.

Case, A., V. Hosegood and F.J. Lund (2005): The reach and impact of child support grants: evidence from KwaZulu-Natal. Development Southern Africa, 22(4): 467482.

Das, J., Q-T. Do and B. Özler (2005): Reassessing conditional cash transfer programs. World Bank Research Observer 20: 57-80.

Department of Public Works (2009): Expanded Public Works Programme: five-year report 2004/05-2008/09. Pretoria: Department of Public Works. 
Department of Social Development (2006): Linking social grants beneficiaries to poverty alleviation and economic activity. Unpublished discussion document. Pretoria: Department of Social Development.

Devereux, S. (2002a): Can social safety nets reduce chronic poverty? Development Policy Review 20(5): 657-675.

Devereux, S. (2002b): From workfare to fair work: the contribution of public works and other labour-based infrastructure programmes to poverty alleviation. Issues in Employment and Poverty Discussion Paper No. 5. Geneva: International Labour Office.

Duflo, E. (2003): Grandmothers and granddaughters: old-age pensions and intrahousehold allocation in South Africa. World Bank Economic Review, 17(1): 125.

Du Toit, A. and D. Neves (2009): Trading on a grant: integrating formal and informal social protection in post-apartheid migrant networks. BWPI Working Paper No. 75. Manchester: University of Manchester (Brooks World Poverty Institute).

Ensor, L. (2010): Unemployment Fund looking at improved benefits, MPs told. Business Day, 23 March 2010.

Online: http://www.businessday.co.za/articles/Content.aspx?id=104265.

Essop, H. and E. Moses (2009): Main findings on free basic services from the National Treasury fiscal incidence report. Stellenbosch Economic Working Papers No 14/09. Stellenbosch: University of Stellenbosch (Department of Economics \& Bureau for Economic Research).

Go, D., M. Kearney, V. Korman, S. Robinson and K. Thierfelder (2009): Wage subsidy and labor market flexibility in South Africa. Policy Research Working Paper No 4871. Washington, D.C.: The World Bank.

Gordhan, P. (2010): Budget speech of the Minister of Finance delivered in the National Assembly on 17 February 2010. Cape Town.

Heintz, J. and D. Posel (2008): Revisiting informal employment and segmentation in the South African labour market. South African Journal of Economics, 76(1): 26-44.

Hodge, D. (2009): Growth, employment and unemployment in South Africa. South African Journal of Economics 77(4): 488-504.

Hudson, J. and S. Kühner (2009): Towards productive welfare? A comparative analysis of 23 OECD countries. Journal of European Social Policy, 19(1): 34-46.

Johannsmeier, C. (2007): The social and economic effects of the disability grant for people with disabilities and their households - a qualitative study in KwaZulu Natal Province. Research Report No. 74. Durban: University of KwaZulu-Natal (School of Development Studies).

Keller, S. (2004): Household formation, poverty and unemployment - the case of rural households in South Africa. South African Journal of Economics, 72(3): 437-483.

Kingdon, G. and J. Knight (2004); Unemployment in South Africa: the nature of the beast. World Development, 32(3): 391-408.

Kingdon, G. and J. Knight (2007); Unemployment in South Africa, 1995-2003: causes, problems and policies. Journal of African Economies, 16(5): 813-848. 
Klasen, S. and I. Woolard (2008): Surviving unemployment without state support: unemployment and household formation in South Africa. Journal of African Economies, 18(1): 1-51.

Leibbrandt, M., I. Woolard, A. Finn and J. Argent (2010): Trends in South African income distribution and poverty since the fall of apartheid. OECD Social, Employment and Migration Working Papers No 101. Paris: Organisation for Economic Co-operation and Development.

Levinsohn, J. (2008): Two policies to alleviate unemployment in South Africa. CID Working Paper No. 166. Cambridge, Mass.: Harvard University (Center for International Development).

Lund, F.J. (1998): Social assistance. Unpublished paper prepared for the Social Policy Project of the Centre for Development and Enterprise. Johannesburg.

Lund, F.J. (2006): Gender and social security in South Africa. In V. Padayachee (Ed.): The Development Decade? South Africa, 1994-2004. Cape Town: HSRC Press: 160-179.

Lund, F.J., M. Noble, H. Barnes and G. Wright (2008): Is there a rationale for conditional cash transfers for children in South Africa? Working Paper No 53. Durban: University of KwaZulu-Natal (School of Development Studies).

Magruder, J.R. (2010): High unemployment yet few small firms: the role of centralized bargaining in South Africa. Berkeley, CA.: University of California at Berkeley (Department of Agricultural and Resource Economics).

Makiwane, M., C. Desmond, L. Richter and E. Udjo (2006): Is the child support grant associated with an increase in teenage fertility in South Africa? Evidence from national surveys and administrative data. Pretoria: Human Sciences Research Council.

Midgley, J. (2008): Welfare reform in the United States: implications for British social policy. CASE Paper No. 131. London: London School of Economics (Centre for Analysis of Social Exclusion).

Mitra, S. (2008): The recent decline in the employment of persons with disabilities in South Africa. South African Journal of Economics, 76(3): 480-492.

National Treasury (2001): Intergovernmental fiscal review 2001. Pretoria: National Treasury.

National Treasury (2004a): Intergovernmental fiscal review 2004. Pretoria: National Treasury.

National Treasury (2004b): Retirement fund reform: a discussion paper. Pretoria: National Treasury.

National Treasury (2005): Intergovernmental fiscal review 2005. Pretoria: National Treasury.

National Treasury (2007a): Social security and retirement reform. Second discussion paper. Pretoria: National Treasury.

National Treasury (2007b): Budget review 2007. Pretoria: National Treasury.

National Treasury (2007c): Estimates of national expenditure 2007. Pretoria: National Treasury.

National Treasury (2008): Budget review 2008. Pretoria: National Treasury.

National Treasury (2008c): Estimates of national expenditure 2008. Pretoria: National Treasury. 
National Treasury (2009a): Budget review 2009. Pretoria: National Treasury.

National Treasury (2009b): Tax statistics 2009. Pretoria: National Treasury.

National Treasury (2009c): Medium-term budget policy statement 2009. Pretoria: National Treasury.

National Treasury (2010a): Budget review 2010. Pretoria: National Treasury.

Nattrass, N. (2006a): Trading off income and health? Aids and the disability grant in South Africa. Journal of Social Policy, 35: 3-19.

Nattrass, N. (2006b). Disability and welfare in South Africa's era of unemployment and Aids. CSSR Working Paper No. 147. Cape Town: University of Cape Town (Centre for Social Science Research).

Noble, M., P. Ntshongwana and R. Surender (2008): Attitudes to work and social security in South Africa. Pretoria: Human Sciences Research Council.

Ochel, W. (2006): Welfare-to-work experiences with specific work-first programmes in selected countries. International Social Security Review, 58(4): 67-93.

Pauw, K. and L. Edwards (2006): Evaluating the general equilibrium effects of a wage subsidy scheme for South Africa. South African Journal of Economics 74(3): 442462.

Pauw, K. and L. Mncube (2007): Expanding the social security net in South Africa: opportunities, challenges and constraints. DPRU Working Paper No. 07/127. Cape Town: University of Cape Town (Development Policy Research Unit).

Posel, D., J.A. Fairburn and F. Lund (2006): Labour migration and households: a reconsideration of the effects of the social pension on labour supply in South Africa. Economic Modelling, 23: 836-853.

Ranchhod, V. (2006): The effect of the South African old age pension on labour supply of the elderly. South African Journal of Economics, 74(4): 725-744.

Rawlings, L. (2005): A new approach to social assistance: Latin America's experience with conditional cash transfer programmes. International Social Security Review 58(2/3): 133-161.

Rawlings, L. and G. Rubio (2005): Evaluating the impact of conditional cash transfer programmes. World Bank Research Observer, 20(1): 29-55.

Samson, M., D. Rosenblum, C. Haarmann, D. Haarmann, K. MacQuene and I. van Niekerk (2001): The socio-economic impact of "workfare": welfare reform lessons from the United States and other international experiences. Research Paper No 26. Cape Town: Economic Policy Research Institute.

Samson, M., U. Lee, A. Ndlebe, K. MacQuene, I. van Niekerk, V. Gandhi, T. Harigaya and C. Abrahams (2004): The social and economic impact of South Africa's social security system. Report commissioned by the Economics and Finance Directorate of the Department of Social Development. Cape Town: Economic Policy Research Institute.

Samson, M., K. MacQuene, I. van Niekerk, S. Kaniki, K. Kallmann and M. Williams (2007): Review of targeting mechanisms, means tests and values for South Africa's social grants. Report commissioned by the Department of Social Development. Cape Town: Economic Policy Research Institute. 
Seekings, J. (2006): Employment guarantee or minimum income? Workfare and welfare in developing countries. USBIG Discussion Paper No. 150. The US Basic Income Guarantee Network.

Sienaert, A. (2008): The labour supply effects of the South African state old age pension: Theory, evidence and implications. SALDRU Working Paper No 20. Cape Town: University of Cape Town (Southern Africa Labour and Development Research Unit).

Smith Committee (2005): Report of the Committee on strategy and policy review retirement provision in South Africa. Pretoria: Department of Finance.

South African Reserve Bank (2009): Quarterly bulletin (September). Pretoria: SARB.

South African Social Security Agency (2009): Statistical report on social grants (28 February 2009). Report No 15 (28 February 2009). Pretoria: SASSA.

Standing, G. (1990): The road to workfare: alternative to welfare or threat to occupation? International Labour Review, 129(6): 677-691.

Statistics South Africa (2008): Income and expenditure survey 2005. Pretoria: Statistics South Africa.

Statistics South Africa (2009a): Quarterly labour force survey (4th $q$ tuarter). Statistical Release P0211. Pretoria: Statistics South Africa.

Statistics South Africa (2009b): GHS series volume 1: Social grants. Statistical Release P0318.1. Pretoria: statistics South Africa.

Tabor, S.R. (2002): Assisting the poor with cash: design and implementation of social transfer programs. Social Protection Discussion Paper No. 223. Washington, D.C.: The World Bank.

Tesliuc, E. (2005): Social safety nets in OECD countries. Social Safety Nets Primer Notes No 25. Washington, D.C.: The World Bank.

The Presidency (2008): Towards an anti-poverty strategy for South Africa. Pretoria: The Presidency.

The Presidency (2009): Development indicators 2009. Pretoria: The Presidency.

Thurlow, J. (2002): Can South Africa afford to become Africa's first welfare state? FCND Working Paper No 139. Washington, D.C.: International Food Policy Research Institute (Food Consumption and Nutrition Division).

Van der Berg, S. (2002): The Basic Income Grant: comments on the report of the Committee of Inquiry into a Comprehensive Social Security System. Johannesburg: SA Foundation.

Van der Berg, S. (2009): Fiscal incidence of social spending in South Africa, 2006. Stellenbosch Economic Working Papers No 10/09. Stellenbosch: University of Stellenbosch (Department of Economics \& Bureau for Economic Research).

Van der Berg, S, M. Louw and D. Yu (2008): Post-transition poverty trends based on an alternative data source. South African Journal of Economics, 76(1): 58-76.

Van der Berg, S., M. Louw and L. du Toit (2009): Poverty trends since the transition: what we know. Stellenbosch Economic Working Papers No 09/09. Stellenbosch: University of Stellenbosch (Department of Economics \& Bureau for Economic Research).

Van der Berg, S, F.K. Siebrits and B. Lekezwa (2009): Efficiency and equity effects of social grants in South Africa. Paper prepared for the Financial and Fiscal 
Commission. Stellenbosch: University of Stellenbosch (Department of Economics).

Venkataramani, A., B. Maughan-Brown, N. Nattrass and J. Ruger (2009): Disability grants and individual and household welfare among HAART patients in South Africa. CSSR Working Paper No. 240. Cape Town: University of Cape Town (Centre for Social Science Research).

Vodopivec, M. (2006): Choosing a system of unemployment income support: guidelines for developing and transition countries. World Bank Research Observer, 21(1): 49-89.

Weigand, C. and M. Grosh (2008): Levels and patterns of safety net spending in developing and transition countries. Social Protection Discussion Paper No 0817. Washington, D.C.: The World Bank.

Why Pigs' mess is our concern. Business Day. Johannesburg, 1 March 2010.

Williams, M.J. (2007): The social and economic impacts of South Africa's child support grant. EPRI Working Paper No. 39. Cape Town: Economic Policy Research Institute.

Woolard, I. (2003): Impact of government programmes using administrative data sets: social assistance grants. Project 6.2 of the Ten Year Review Research Programme. Online: http://www.sarpn.org.za.

Yaqub, S. (1999): How equitable is public spending on health and education? Background paper prepared for World Development Report 2001. Sussex: University of Sussex (Poverty Research Unit).

Yamauchi, F. (2005): Early childhood nutrition, schooling and within-sibling inequality in a dynamic context: Evidence from South Africa. FCND Discussion Paper No. 203. Washington, D.C.: International Food Policy Research Institute (Food Consumption and Nutrition Division).

$\mathrm{Yu}$, D. (2008): The South African labour market, 1995-2006. Stellenbosch Economic Working Papers No 05/08. Stellenbosch: University of Stellenbosch (Department of Economics \& Bureau for Economic Research). 